\title{
Understanding absorptive capacities in an 'innovation systems' context: consequences for economic and employment growth
}

Citation for published version (APA):

Narula, R. (2004). Understanding absorptive capacities in an 'innovation systems' context: consequences for economic and employment growth. MERIT, Maastricht Economic Research Institute on Innovation and Technology. MERIT-Infonomics Research Memorandum Series No. 003 https://doi.org/10.26481/umamer.2004003

Document status and date:

Published: 01/01/2004

DOI:

10.26481/umamer.2004003

Document Version:

Publisher's PDF, also known as Version of record

Please check the document version of this publication:

- A submitted manuscript is the version of the article upon submission and before peer-review. There can be important differences between the submitted version and the official published version of record.

People interested in the research are advised to contact the author for the final version of the publication, or visit the DOI to the publisher's website.

- The final author version and the galley proof are versions of the publication after peer review.

- The final published version features the final layout of the paper including the volume, issue and page numbers.

Link to publication

\footnotetext{
General rights rights.

- You may freely distribute the URL identifying the publication in the public portal. please follow below link for the End User Agreement:

www.umlib.nl/taverne-license

Take down policy

If you believe that this document breaches copyright please contact us at:

repository@maastrichtuniversity.nl

providing details and we will investigate your claim.
}

Copyright and moral rights for the publications made accessible in the public portal are retained by the authors and/or other copyright owners and it is a condition of accessing publications that users recognise and abide by the legal requirements associated with these

- Users may download and print one copy of any publication from the public portal for the purpose of private study or research.

- You may not further distribute the material or use it for any profit-making activity or commercial gain

If the publication is distributed under the terms of Article $25 \mathrm{fa}$ of the Dutch Copyright Act, indicated by the "Taverne" license above, 


\section{MERIT-Infonomics Research Memorandum series}

Understanding absorptive capacities in an "innovation Systems" context: consequences for economic and employment growth.

\section{Rajneesh Narula}

2004-003
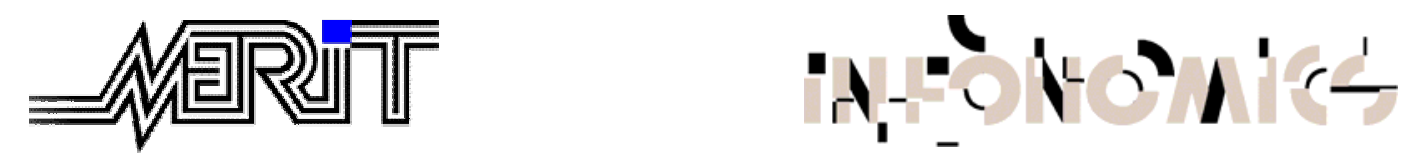

MERIT - Maastricht Economic Research

International Institute of Infonomics

Institute on Innovation and Technology

PO Box 616

6200 MD Maastricht

The Netherlands

$\mathrm{T}:+31433883875$

F: +31433884905

c/o Maastricht University

PO Box 616

6200 MD Maastricht

The Netherlands

T: +31433883875

F: +31453884905

http://www.merit.unimaas.nl

http://www.infonomics.nl

e-mail:secr-merit@merit.unimaas.nl

e-mail: secr@infonomics.nl 


\title{
Understanding absorptive capacities in an "innovation systems" context: consequences for economic and employment growth ${ }^{1}$
}

\author{
Rajneesh Narula \\ Copenhagen Business School \& University of Oslo \\ rn.int@cbs.dk
}

\section{Prepared for the ILO, background paper for the World Employment Report 2004 \\ Version December 2003}

\begin{abstract}
This paper seeks to broaden our understanding of the concept underlying absorptive capacity at the macro -level, paying particular attention to the growth and development perspectives. We provide definitions of absorptive and technological capacity, external technology flows, productivity growth, employment creation and their interrelations. We then analyse the elements of absorptive capability, focusing on the nature of the relationship within a systems view of an economy, focusing primarily on the role of firm and non-firm actors and the institutions that connect them, both within and across borders. We also undertake to explain how the nature of absorptive capacity changes with stages of economic development, and the importance of the different aspects of absorptive capability at different stages. The relationship is not a linear one: the benefits that accrue from marginal increases in absorptive capability change over time. Finally, we provide a tentative and preliminary conceptual argument of how the different stages of absorptive capacity are related to productivity growth, economic growth and employment creation.
\end{abstract}

Key words: absorptive capacity, development, infrastructure, FDI, growth, systems, innovation, employment, institutions, multinationals, human capital

\footnotetext{
${ }^{1}$ Special thanks to Evis Sinani for her research assistance. Comments from Sara McGaughey and Lars Håkanson on an earlier draft are much appreciated. Several of the concepts described in this paper are based on ideas developed in collaboration with Paola Criscuolo and Anabel Marin. I gratefully acknowledge their indirect input. All errors remain my own.
} 


\section{Introduction}

It is by now axiomatic that economic growth occurs due to the ability of a nation's industries to develop and sustain their competitive position, and that this requires growth in the productivity of its capital and labour. ${ }^{2}$ Further, economic growth concerns not just the acquisition and development of knowledge through innovation and learning, but also the diffusion and efficient utilization of this knowledge.

Productivity growth among developing countries relies considerably on the ability of its economic units to acquire and internalize knowledge developed elsewhere if they are to "catch up”. Laggard “economic units” (countries or firms) must possess the ability to absorb, internalize and utilize the knowledge potentially made available to them. This ability is known as "absorptive capacity", or the appropriate supply of human capital and technological capability to be able to generate new technologies and consequently use productive resources efficiently. In turn, this is expected to translate into productivity growth for firms as well as countries.

Not all countries are able to catch up at the same rate or to the same extent. As this paper explores, the nature of the potential and the capabilities of any given country to absorb external knowledge is a function of (inter alia) its stage of development.

It is important to assert two points before proceeding with this analysis. First, absorptive capacity per se has little or no influence on productivity, economic growth or employment. That is, it is an inert concept - much like an enzyme - that only has significance as a catalyst, helping to metabolize technology flows. Technology flows can be embodied in foreign direct investment (FDI), intermediate goods, capital equipment, or licensing, but may have little or no effect on development or growth without absorptive capacity. In this paper, we do not describe the processes whereby absorptive capacity interacts with technology flows, or how spillovers and linkages

\footnotetext{
${ }^{2}$ See Fagerberg (1994) for a review.
} 
arise therefrom, although we assume such an interaction is taking place and that it is happening in an efficient manner. ${ }^{3}$ Underlying this assumption is the further assumption that technology flows are optimally available.

Second, economic growth is only weakly related to growth of employment. That is, economic growth does not always result in increases in the quantity of employment, since increases in productivity may well result in the same (or fewer) workers producing the same (or greater) output. Likewise, new technologies may require a lower quality of employment due to increased automation. Furthermore - as we shall discuss in this paper - where productivity results in an increase in quantity or quality of employment, the same mechanisms do not necessarily provide the same benefits for countries at different stages of economic development or resource endowments. The relationship is stage-dependent, non-linear and non-monotonic.

We would like to emphasize that this is not to say that absorptive capacity and employment are unrelated. But the current evidence is unanimous in asserting a strong correlation between economic growth and the absorptive capacity. There is also sufficient evidence to suggest that positive economic growth is closely correlated with an increase in a nation's absorptive capacity (although there are other intervening factors, see e.g., Abramovitz 1986, 1995, Dahlman and Nelson 1995). However, at certain stages of development this results in structural upgrading and it may affect the quality of employment, which may sometimes occur at the expense of aggregate (quantity) of employment. At other stages, economic growth is associated with a decline in quality and quantity of employment.

This paper is organized as follows. First, we provide definitions of absorptive and technological capacity, external technology flows, productivity growth, employment creation and their interrelations. We present our preliminary assumptions and caveats of our analysis. Second, we analyse the elements of absorptive capability, focusing on the nature of the relationship within a systems view of an economy, focusing primarily on the role of firm and non-firm actors (which include the

\footnotetext{
${ }^{3}$ This is the subject of a vast literature, because there is considerable evidence to suggest that external knowledge is not always efficiently internalized by domestic firms, even where absorptive capacity may be present. For recent reviews, see e.g., JIBICI (2002) and Narula and Marin (2003).
} 
infrastructural and demand related issues) and the institutions that connect them, both within and across borders. Third, we undertake to explain how the nature of absorptive capacity changes with stages of economic development, and the importance of the different aspects of absorptive capability at different stages. The relationship is not a linear one: the benefits that accrue from marginal increases in absorptive capability change over time This point is illustrated with examples and some explanatory tables of indicators. Fourth, we provide a tentative and preliminary conceptual argument of how the different stages of absorptive capacity are related to productivity growth, economic growth and employment creation.

\section{Defining concepts and relationships}

Firms expand their activities depending upon the strength (or weakness) of their competitive assets. These are not only confined to technological assets in the sense of ownership of plant, equipment and technical knowledge embodied in their engineers and scientists. Firms of all sizes also possess competitive advantages that derive from (a) the ability (i.e., knowledge) to create efficient internal hierarchies (or internal markets) within the boundaries of the firm, and (b) from being able to utilize external markets efficiently. These firm-specific assets are unique to each individual firm, because firms themselves consist of uniquely individual human beings. Even where two firms are identical in terms of products and markets, one may be more profitable than the other because its managers are more efficient in utilizing its resources. Some firm-specific assets are associated with the efficiency with which hierarchies are organized and referred to as organizational innovations. ${ }^{4}$ Improvements in the quality of these assets also leads to a greater quality per unit price, thus they can be regarded as innovations and as part of the firm's core assets. Such assets form a necessary and (and sometimes sufficient) basis for a firm to remain competitive. They include inter

\footnotetext{
${ }^{4}$ For an excellent discussion on the differences between product and process innovations (which includes organizational innovation) from a systems of innovation perspective, see Edquist, Hommen and McKelvey (2001).
} 
alia knowledge of overseas locations, capabilities associated with organizing multilocation operations, marketing and logistics, transfer pricing, etc. If we accept that it is the cumulation of technological assets and transaction-type assets which determine the competitiveness of firms, we also accept that the cumulation of firms' competitiveness determines the competitiveness of countries. We can thus further accept that economic growth occurs due to the ability of a country's industries to develop and sustain their competitive position - and that this requires growth of productivity of its capital and labour - then we may postulate that economic growth concerns not just the development of knowledge through innovation, but also the diffusion of knowledge such that it may be utilized and exploited in an efficient manner. In other words, accumulated technology is an engine of growth only if it can be harnessed to make the best use of the available resources and, therefore, must also consist of the knowledge to organize transactions efficiently, whether intra-firm, intraindustry or intra-market. Firm-specific assets - be they technological in the narrow sense, or organizational - all share the common characteristics that they are cumulative and evolve over time. That is, firms seek to maintain a stock of these assets, and learn.

Knowledge development - like all forms of learning - can be either incremental or radical, depending on a variety of factors. In the case of incremental learning, economic units - be they firms or individuals - acquire knowledge by exploring in the vicinity of their existing knowledge assets, by undertaking routines, which leads to incremental innovations (learning-by-doing). Knowledge is acquired by interaction with its external environment. In the case of firms it may be through interaction (inter alia) with customers, suppliers, competitors, government agencies. This is referred to as learning-by-interacting. Firms (and the individuals they comprise) are generally averse to radical change and are likely to "stay close" to the patterns of behaviour, learning and interaction that have been successful in the past. This is referred to as routinized learning.

Routinized learning can be further characterized as "exploitative learning” which adds to the existing knowledge and competencies of a firm without fundamentally changing the nature of its activities. Radical or non-routinized learning 
or "exploratory learning”, involve changes in company routines and experimentation with new alternatives.

These evolutionary processes do not occur in a vacuum. Firms do not make decisions - about the kinds of products they will seek to develop, or where they intend to develop and produce these goods and services - based simply on firm-specific issues and profit-maximizing motives (see Hagedoorn and Narula 2001). Firms exist as part of "systems". That is, they are embedded through historical, social and economic ties to other economic units.

Finally, economic units of whatever size have finite resources. There are cognitive limits to what a firm can and cannot do, because it is constrained by its asset base or its potential to acquire these. Resources also include managerial assets, and other ownership advantages - all of them finite. Firms are also constrained by the kinds of knowledge competence they can acquire and internalize by the extent of their absorptive capabilities.

Absorptive capacity has been more extensively analysed at the firm level, where technological learning and technological change take place, and where available data have allowed researchers to assess the role of absorptive capacity in the firm's innovation performance ${ }^{5}$ (Cohen and Levinthal 1989, 1990). In their seminal 1989 article, Cohen and Levinthal define absorptive capacity as "the firm's ability to identify, assimilate, and exploit knowledge from the environment”. It is important to note that absorptive capacity is a subset of technological capability, which in addition to absorptive capacity includes the ability to generate new technologies through innovative means.

There is considerably less work on understanding the nature of absorptive capacity on the national level. Dahlman and Nelson (1995) define national absorptive capacity as "the ability to learn and implement the technologies and associated practices of already developed countries”. National absorptive capacity is more than the sum of the absorptive capabilities of domestic firms (this is discussed further in the next section). In order to understand the notion of national absorptive capacity one

\footnotetext{
${ }^{5}$ For a review of the literature on firm-level analysis of absorptive capacity, see Zahra and George (2002).
} 
should keep in mind that a country's absorptive capacity is not simply an aggregation of its firms or its industries. There are other additional multiplicative effects which, although insignificant at firm level, become very significant at the national level. Given that national absorptive capacity is influenced by external technological environment, it is salient to point out that firms operate within systems and that countries, like firms, are not isolated from outside knowledge. Hence, absorptive capacity may be affected by the stock of knowledge of firms of other countries. Criscuolo and Narula (2002) highlight the importance of national absorptive capacity and knowledge accumulation. By aggregating upwards from firm level they specify the relationship between the ability of a country to absorb foreign knowledge and its stages of technological development. ${ }^{6}$ It should be emphasized that absorptive capacity (as defined in the literature) is fundamentally different from the capability to absorb: the latter always increases, whereas the former is a function of the amount of knowledge that remains to be assimilated. To illustrate the difference take a world of finite knowledge. When all available knowledge has been absorbed, absorptive capacity is zero, but the capability to absorb remains high.

The concept of national absorptive capacity has so far been associated in the international technology transfer literature with the broader concept of national technological capabilities. According to Fransman (1984: 10) these capabilities involve

... the search for available alternative technologies and the selection of the most appropriate technology; the mastering of technology, that is, its successful use in the transforming of inputs into outputs; the adaptation of the technology in order to specific production condition; the further development of the technology as the result of minor innovations; the institutionalised search for more important innovations with the development of $R \& D$ facilities; the conducting of basic research.

\footnotetext{
${ }^{6}$ The relation between absorptive capacity and development stages is described in more detail in Part 3 of this report.
} 
Absorptive capacity includes the ability to search and select the most appropriate technology to be assimilated from existing ones available, as well as the activities associated with creating new knowledge. Absorptive capacity also reflects the ability of a country to integrate the existing and exploitable resources technological opportunities - into the production chain, and the foresight to anticipate potential and relevant technological trajectories. This ability is therefore affected by the international technological environment. It is important to emphasize that absorption is not purely about imitation. Firms cannot absorb outside knowledge unless they invest in their own capacity to innovate - because it can be highly specific to the originating firm, since it has a partly tacit nature. The extent to which a firm is able to exploit external sources of knowledge thus depends on its absorptive capacity, which is assumed to be a function of its innovative efforts and the degree to which outside knowledge corresponds to the firm's needs, as well as the general complexity of the knowledge target.

\section{Unravelling absorptive capacity}

It is important to understand the components of absorptive capacity if we are to understand how it influences economic growth and affects employment. National absorptive capacity is not simply an aggregation of the absorptive capacity of a nation's industries. There are numerous additional, combinatory and multiplier effects which - although negligible at the firm-level - take on considerable significance at the national level. As with firms, so with nations: absorptive capacity includes not only the ability of creating new knowledge through investment in knowledge, but also the ability to search and select the most appropriate technology to be assimilated from existing ones available to other economic actors. Countries in any given industry follow a trajectory of technological accumulation. Laggard economic units (be they countries or firms) must possess (inter alia) the ability to absorb and internalize knowledge potentially made available to them. To put it simplistically, if the institutions and organizations are absent or underdeveloped, economic actors within the system will be unable to absorb and efficiently internalize knowledge. 
By economic actors we refer to two groups. The first group are firms - private and public - engaged in innovatory activity. The second consists of non-firms that determine the knowledge infrastructure which supplements and supports firm-specific innovation. We define "knowledge infrastructure" in the sense proposed by Smith (1997) as being “generic, multi-user and indivisible” and consisting of public research institutes, universities, organizations for standards, intellectual property protection, etc., the infrastructure that enables and promotes science and technology development.

Absorptive capacity is significant for development because it allows domestic economic actors to internalize knowledge that exists elsewhere (either within the domestic economy or externally) that is made available directly or indirectly to them. Box 3.1 shows several ways in which technology flows occur, either through armslength means, such as through licensing, or through trade in intermediate goods, plant and equipment or even products or services. However, technology flows may also be made available through hierarchies, between affiliated firms within a multinational enterprise (MNE) or through the modality of FDI. Although not the only means available, spillovers from FDI are regarded as one of the most practical and efficient means by which industrial development and upgrading can be promoted (Narula and Dunning 2000). While the potential for MNC-related spillovers are clear, as are the opportunities for industrial upgrading therefrom, it is increasingly acknowledged that the nature, level and extent of the benefits vary considerably. 


\section{Box 3.1 Technology flows}

Technology flows may occur through various means:

1. Through trade, embodied in;

- $\quad$ Plant and equipment

- Intermediate and final goods or other imports

2. Through hierarchies (i.e., inward FDI, such as MNEs), embodied in:

- Expatriate personnel

- Plant and equipment

- Intermediate and final goods

- Training provided to employees

- Intra-firm, inter-subsidiary movement of staff

- Inter-MNE alliances

3. Arms-length through:

- turn-key projects

- consultancy projects

- licensing

- franchising

4. Outward FDI (through reverse technology transfer)

The point we are raising here is that for any kind of spillovers to be efficiently internalized by the domestic economy, two conditions need to be satisfied. First, spillovers must exist. Second, domestic economic actors must possess the appropriate level of absorptive capacity. Thus, even where technological assets are made available - either through licensing or indirectly through spillovers from inward FDI - the domestic sector may not be in a position to internalize these assets. Borenzstein et al. (1998) and Xu (2000) have shown that FDI has a positive impact on economic growth only in those developing countries that have attained a certain minimum level of absorptive capacity. Knowledge accumulation is much more rapid once the initial threshold level of absorptive capacity exists. Simply put, technology absorption is easier, once countries have "learned-to-learn” (Criscuolo and Narula 2002). The cost of imitation increases as the follower closes the gap with the leader and the number of technologies potentially available for imitation reduces. This implies that there are diminishing returns on marginal increases in absorptive capacity as firms approach the frontier of knowledge (Narula 2003a). The frontier is defined as the set of all production methods that at a given point in time are the most efficient in the world. 
The interpretation of an aggregate technological frontier as used here is necessarily a stylized, static and nominal concept, since in reality there is no such thing as a knowable, fixed technological frontier on an aggregate basis. However, for pedagogical purposes it is necessary to use such a nominal concept.

Thus, technology flows - be they through hierarchies or arms-length - are not a sine qua non for development, without the presence of domestic economic actors. Likewise, the presence of domestic economic actors per se is a necessary but insufficient condition, without the presence of an appropriate level of absorptive capacity.

The capacity to absorb on a national level is a function of not just the firms within an economy. It is important to understand that while learning and absorption take place at the firm level, the success or failure of individual firms occurs in orchestration with an entire "system". ${ }^{7}$ Within any system, there exists a broader nonfirm-specific knowledge base within what might best be described as "non-firm actors" that are crucial to a country-level understanding of the process of technological accumulation. Innovation involves complex interactions between a firm and its environment. The environment consists firstly of interactions between firms especially between a firm and its network of customers and suppliers. Secondly, the environment involves broader factors shaping the behaviour of firms: the social and perhaps cultural context; the institutional and organizational framework; infrastructures; the processes which create and distribute scientific knowledge, and so on. This has led to a systems approach to understanding innovation. Box 3.2 broadly defines the difference between innovations and inventions.

Box 3.2 Understanding the difference between innovations and inventions

"Innovation" may mean the introduction of any novelty, but in the economics and technology literature it has come to have a more precise meaning or meanings since Schumpeter made his distinction between "invention" and “innovation". An invention is an idea, sketch or model of any new or improved device, product,

\footnotetext{
${ }^{7}$ These have been referred to as innovation systems (see e.g., Lundvall 1992, Edquist 1997, Narula 2003a) or learning systems (Lall 1992, Viotti 2002).
} 
process or system. Innovations only occur when the new product, device or process is involved in a commercial transaction. Multiple inventions may be involved in achieving an innovation. In the Schumpeterian sense, scientific discoveries as well as inventions would not come within the compass of innovation, although they might fall within a second, broader, type of definition, which is concerned with the entire process of an innovation, including antecedent work not necessarily undertaken by the entrepreneur who attempts the first type. The broad definition of innovation as used here implies changes in the knowledge, ability and techniques required to produce goods and services of higher or better quality per unit price, while technology represents the cumulative stock of these innovations. Technology as used here therefore includes all activities that provide assets with which an economic unit can generate product or services. Science provides us with more generic knowledge, which may or may not generate products and services.

Source: Adapted from Narula (2003a).

The use of the word "system" does not necessarily mean that the various influences that underpin the generation of industrial innovation are systematically organized (Narula 2003a). To put it in simplistic terms, "system” is taken to mean a regularly interacting or interdependent group forming a unified whole. It is probably more accurate to say that an innovation system in most cases represents the serendipitous intertwining of institutions and economic actors within industry which defined the stock of knowledge in a given location (Etzkowitz and Leydesdorff 2000). Changes in, say, the educational priorities of a new government, are likely to affect other institutions, and eventually, the nature of innovatory activities of firms within given industries, thereby influencing the process and extent of technological learning in future periods.

By institutions, we mean the "sets of common habits, routines, established practices, rules, or laws that regulate the interaction between individuals and groups" (Edquist and Johnson 1997). Institutions create the milieu within which innovation is

\footnotetext{
8 These have been referred to as innovation systems (see e.g., Lundvall 1992, Edquist 1997, Narula 2003a) or learning systems (Lall 1992, Viotti 2002).
} 
undertaken; they establish the ground rules for interaction between the various economic actors and represent a sort of “culture”. Institutions are associated with public-sector organizations, but are not exclusively so. Institutions create the milieu within which innovation is undertaken and establish the ground rules for interaction between the various economic actors, and represent a sort of a 'culture' of innovation and therefore influence the dynamics of the learning process (Freeman 1992, Johnson 1992, Narula 2003a). It is not only the creation of new knowledge but also the diffusion of extant knowledge which determines the effective national technological knowledge stock and thus the accumulation of national absorptive capacity.

Knowledge creation is often associated with formal activities within research and development (R\&D) that is undertaken in a systematic manner within universities, specialized public and private R\&D facilities. However, these formal means represent only a small proportion of knowledge creation. Knowledge creation is a much larger and more systemic phenomenon, although formal facilities account for a large percentage of output. As Freeman and Soete (1997: 45) explain:

But this [formal] Research and Development system is at the heart of the whole complex, for in contemporary society it originates a large proportion of the new and improved materials, products, processes and systems, which are the ultimate source of economic advance. This is not to underestimate the importance of dissemination of knowledge through the education system, industrial training, the mass media, information services and other means. Nor is it to deny the obvious fact that in the short run rapid progress may be made by simply by the application of the existing stock of knowledge. Nor yet is it to deny the importance of feedback from production and from markets to R\&D and scientific activities. It is only to assert that the fundamental point that for any given technique of production, transport or distribution, there are long-run limitations on the growth of productivity, which are technologically determined. In the most fundamental sense the winning of new knowledge is the basis for human civilisation. 
As Figure 3.1 shows, knowledge creation within an economy is fostered by two groups of actors. First, by firms (whether domestic or foreign), who undertake formal and informal $R \& D$, as well as providing training to their employees. Firms are constituted of appropriately qualified and trained employees who, in conjunction with other factors of production, allow them to internalize spillovers efficiently. Because technologies - no matter how generic - have a certain firm-specific aspect to them. Any form of knowledge spillover needs to be decoded from the transmitter's firmspecific context to that of the receiver's (Cantwell 1991). In other words, absorption is not purely about imitation. Because outside knowledge can be highly specific to the originating firm and be partly tacit in nature, firms cannot absorb such knowledge unless they invest in their own R\&D. Absorptive capacity is a function not just of a firm's R\&D efforts, but also of the degree to which outside knowledge corresponds to the firm's needs, and the general complexity of external knowledge. Second, knowledge creation is undertaken by non-firm actors, such as universities, statesubsidized R\&D organizations and standards-setting bodies. Non-firm actors act very much as support organizations for firm actors, but their role is by no means secondary (Figure 3.1 and Box 3.3).

From a human capital perspective, the non-firm sector is crucial in two ways. First, the country must be able to provide appropriately educated employees to firms. Domestic firms that internalize spillovers need be constituted of appropriately qualified and trained employees who, in conjunction with other factors of production, allow these domestic firms to internalize spillovers efficiently. Appropriate education is not, of course, limited to training and qualifications related to specific functions of the firm: some firms seek trainable employees (i.e., personnel who have "learned to learn”) and then train them to provide the skills needed to perform specialized tasks. It is important to stress, however, that while human capital represents a "core" location advantage and a primary determinant of investment, not all investment is associated with the presence of a skilled workforce. Indeed, studies have shown that certain kinds of investment is directed to locations where absorptive capacity is low, in that firms seek untrained labour to perform simple assembly-type or resource extractive activities (Narula and Wakelin 1998). Indeed, it may be that MNEs actively seek locations with low-skilled workers (Narula 1996). As discussed in the previous 
section, the motive of investment plays a significant role in determining what kinds of human resources firm seek, and to what extent firms will undertake the training of employees.

Second, in addition to providing appropriate training and education to generate potential employees of foreign and domestically owned firms, support organizations in the non-firm sector provide quasi-public goods in the form of innovative output and capacity. Progress towards more technology-intensive manufacturing and service activities depends on the existence of "hi-tech infrastructure” (Rasiah 2002). This infrastructure includes universities and polytechnics capable of generating skilled technicians, engineers and scientists, as well as undertaking some level of basic and applied research and development. Less obvious is the institutional standard infrastructure, with standards-setting processes providing forums in which diverse stakeholders can develop and disseminate their ideas (McGaughey 1998). Such infrastructure plays an important role in promoting the innovatory and absorptive capacity of firms. It also acts as a mechanism to “direct” technology strategy and as a mechanism to overcome market failure.

It is worth emphasizing that hi-tech infrastructure is only a supplement to "basic infrastructure" which includes the provision of electricity, telephones, postal services, hospitals, public transport, road, railways, etc. In addition, however it also includes primary and secondary education. 
Figure 3.1: The components of absorptive capacity within an innovation system in an international environment

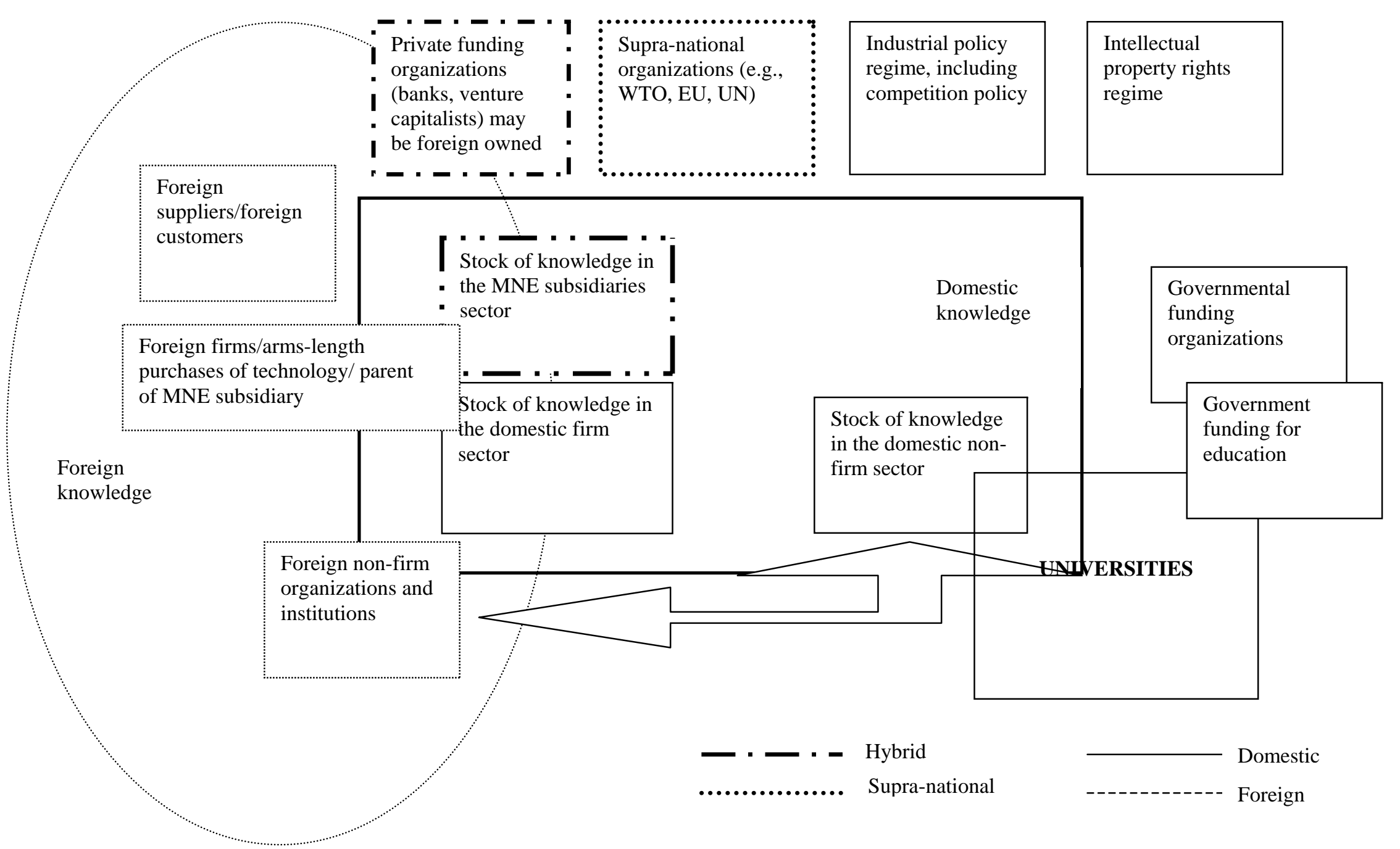

Source: Narula (2003a) 
It should also be stressed that while human capital represents a core aspect of absorptive capacity, its presence is also not a sufficient condition for knowledge accumulation. This requires the presence of institutions and economic actors that determine the stock of knowledge in a given location and the efficient use of markets and hierarchies - be they intra-firm, intra-industry or intra-country. This knowledge is not costless and must be accumulated over time. While physical and human capital are necessary conditions for catching-up, the lack of appropriate incentives for production and investment can compromise the success of the technological upgrading (Lall 1992). The availability of a large stock of suitably qualified workers does not in itself result in efficient absorption of knowledge, although the definition of human capital shares some commonality with the concept of absorptive capacity. For example, several empirical studies have in fact used human capital measures as proxies for absorptive capacity (see Verspagen 1991 and Borenzstein et al. 1998).

Both human capital and absorptive capacity involve learning activities and therefore are cumulative processes: the competence “...to evaluate and utilize outside knowledge is largely a function of the level of prior related knowledge" (Cohen and Levinthal 1990: 128). Qualified human resources are essential in monitoring the evolution of external knowledge and in evaluating its relevance, and for the integration of these technologies into productive activities.

In examining the link between absorptive capacity and productivity growth we should bear in mind the importance of the minimum required level of absorptive capacity. As stressed above, the existence of an external stock of knowledge does not automatically imply efficient internalization on the part of nations because knowledge can be specific to the originating source. Hence, a country should possess a minimum threshold stock of knowledge that will allow it to absorb external knowledge. This absorption should lead to higher productivity growth. For instance, Borensztein et. al. (1998) show that, at country level, a minimum threshold of absorptive capacity is necessary for FDI to contribute to higher productivity growth, while Narula and Marin (2003) show that only firms with high absorptive capacity are likely to benefit from FDI spillovers. In other words, possessing educated people is a precondition for a country's increased absorptive capacity, which contributes to enhanced productivity. Likewise, Xu (2000) shows that a 
country needs to reach a minimum human capital threshold level in order to benefit from technology transfer. The absence of sufficient levels of absorptive capacity tends to lead to the inefficient use of technology flows.

\section{Box 3.3 The components of absorptive capacity}

\section{Basic infrastructure}

Roads, railways, etc.

Telephones

Electricity

Basic skilled human capital (primary and secondary education)

Primary and secondary schools

Hospitals

\section{Advanced infrastructure}

Universities

Advanced skilled human capital (tertiary education)

Research institutes

Banks, insurance firms

\section{Firms}

Domestic firms with appropriate human and physical capital to internalize technology flows.

MNE affiliates (acting both as users and creators of technology flows)

\section{Formal and informal institutions}

Intellectual property rights regime

Technical standards, weights and measures

Incentives and subsidies to promote adoption and creation of new technologies

Taxation

Competition policy

Investment promotion and targeting schemes.

Promotion of collaboration between economic actors (domestic)

Promotion of collaboration between economic actors (foreign)

Promoting entrepreneurship

Finally, it is worth noting that government policies are essential to promote interlinkages between the different elements of absorptive capacity, as well as to create the opportunities for economic actors to absorb and internalize spillovers. These include both formal and informal institutions. The importance of institution-creation cannot be overstated: Rodrik et al. (2002) demonstrate that efficient institutions contribute more to 
economic growth than location or trade. The area of formal institutions include the appropriate intellectual property rights regime, competition policy, the creation of technical standards, taxation, the establishment of incentives and subsidies for innovation, the funding of education, etc (see Box 3.3). Informal institutions are much more difficult to quantify, but are associated with creating and promoting links between the various actors (see Box 3.3). For example, by encouraging firms and individuals to approach and collaborate with universities or by promoting entrepreneurial spirit, governments play several important roles. The work of Lall (see for instance 1996, 1997a, 1997b, 2003a) points to the need of a holistic approach to selecting and leveraging sectors for dynamic growth, for stable governments, transparent policies, and the provision of basic infrastructure and skills. The role of governments as a market facilitator and provider of complementarily created, location-specific assets is more critical (Narula 2003a). 


\section{The international aspect of absorptive capacity and growth}

In a purely domestic innovation system, the path of technological development is determined primarily by domestic elements. The technological development trajectory would be driven largely by the changing demand of local customers. Likewise, domestic governmental organizations would determine domestic industrial policy, which in turn would determine domestic industrial structure. National non-firm sources of knowledge and national universities also determine the kinds of skills that engineers and scientists possess, and the kinds of technology in which these individuals have appropriate expertise, the kinds of technology in which basic and applied research is conducted and, thereby, the industrial specialization and competitive advantages of the firm sector.

Some systems have a greater cross-border aspect than others, but there are few purely domestic systems. As such, most learning processes are not just limited to intranational interaction, but increasingly include international interaction. The pervasive role of MNEs in a globalizing world - and their ability to utilize technological resources located elsewhere - makes the use of a purely national system of innovation rather limiting. Broadly speaking, individual national systems remain distinct. Despite the economic and technological convergence associated with economic globalization, technological specialization patterns are distinct across countries (Narula 1996). The sources of knowledge available in a typical "national" system are a complex blend of domestic and foreign components, as illustrated in the simplified (and stylized) framework depicted in Figure 3.1.

However, few - if any - such domestic systems exist. In some countries, it is increasingly difficult to separate foreign knowledge sources from domestic ones. MNE subsidiaries are sometimes so well embedded that they are regarded as part of the domestic environment. Nonetheless, the interaction between the domestic firm sector and the foreign-owned firm sector varies considerably, either because the domestic sector is largely in different sectors, or because the two have evolved separately. Katrak (2002) shows that in the case of India, MNEs tend to benefit from knowledge spillovers from other MNEs, rather than to (or from) domestically owned firms. 
Box 4.1 takes a look at the importance of MNEs as a share of the world's economic activities.

\section{Box 4.1 The role of MNEs in global human capital: Why the fuss?}

Despite the importance given to MNEs, they do not account for a dominant or even a major share of the world's economic activity. As Table B4.1 shows, in terms of employment, the 100 world' top non-financial MNEs employed 14.3 million of the total 1.8 billion people employed worldwide in 2000, which represents less than 1 per cent of total employment. Examining the same ratio for the entire universe of MNEs worldwide in the same year, MNEs employed only 3.5 per cent of the total world economically active population (EAP) and 6 per cent of total people employed around the world.

Table B4.1: The role of MNEs in global employment, 2000 (in thousands)

\begin{tabular}{llll}
\hline Regions & Total Population & $\begin{array}{l}\text { Economically active } \\
\text { population (EAP) }\end{array}$ & $\begin{array}{l}\text { Total Employed } \\
\text { population }\end{array}$ \\
\hline World & $6,056,307.00$ & $2,947,598.00$ & $1,825,629.00$ \\
More developed regions & $1,191,021.00$ & $601,011.00$ & 393976.20 \\
Less developed regions & $4,865,286.00$ & $2,346,586.00$ & 1431652.00 \\
Top 100 MNEs & & $14,300.00$ & 14300.00 \\
All MNEs & & $102,140.00$ & 102140 \\
All MNEs as \% of world & & $3.5 \%$ & $5.6 \%$ \\
\hline
\end{tabular}

Note: The information on employment is not complete for developing countries. The ILO provides information on employment in the 1990s for 127 of 242 countries. Nevertheless, as all the major recipients of FDI are included, the estimations can be considered to be largely accurate. Source: LABORSTAT database (ILO) and World Investment Report 2001 (UNCTAD).

MNEs play an even less significant role in the developing regions, where MNEs are estimated to represent less than 2 per cent of total employment. Thus, the contribution to domestic employment from FDI does not seem very impressive, from a quantitative point of view at least.

Despite the relatively small role of MNEs on an aggregate level, the situations differ substantially across countries. As Table B4.2 shows, MNEs account for less than 5 per cent of the total employment in countries such as Japan and Indonesia, but this figure rises to well over 40 per cent in countries such as Malaysia, Argentina and Ireland. 
Table B4.2:FDI participation in total employment by \begin{tabular}{|l|l|l|}
\hline Country & Year & Percentage of workers employed
\end{tabular}

\begin{tabular}{|l|l|} 
& \multicolumn{2}{|c|}{ by MNEs } \\
\hline & Manufacturing All industries \\
\hline
\end{tabular}

DEVELOPED COUNTRIES

\begin{tabular}{|c|c|c|c|}
\hline \multirow[t]{2}{*}{ Austria } & 1988 & NA & 9.8 \\
\hline & 1996 & 19.8 & 9.9 \\
\hline \multirow[t]{2}{*}{ Finland } & 1992 & 5.3 & 1.8 \\
\hline & 1997 & 12.5 & 6.7 \\
\hline \multirow[t]{2}{*}{ France } & 1987 & 16.8 & NA \\
\hline & 1992 & 16.9 & NA \\
\hline \multirow[t]{2}{*}{ Germany } & 1985 & 6.6 & NA \\
\hline & 1996 & 13.0 & 5.1 \\
\hline \multirow[t]{2}{*}{ Ireland } & 1985 & 40.9 & NA \\
\hline & 1990 & 45.6 & NA \\
\hline \multirow[t]{2}{*}{ Italy } & 1985 & 16.0 & NA \\
\hline & 1993 & 17.4 & NA \\
\hline \multirow[t]{2}{*}{ Japan } & 1985 & 0.6 & 0.3 \\
\hline & 1995 & 1.2 & 0.5 \\
\hline \multirow[t]{2}{*}{ Netherlands } & 1985 & 15.2 & 4.9 \\
\hline & 1994 & 19.1 & NA \\
\hline \multirow[t]{2}{*}{ Norway } & 1985 & 7.4 & NA \\
\hline & 1994 & 9.0 & NA \\
\hline \multirow[t]{2}{*}{ Sweden } & 1985 & 7.7 & 2.7 \\
\hline & 1996 & 18.0 & 7 \\
\hline \multirow[t]{2}{*}{ U Kingdom } & 1985 & 13.7 & NA \\
\hline & 1992 & 18.2 & NA \\
\hline \multirow[t]{2}{*}{ United States } & 1985 & 7.0 & 2.7 \\
\hline & 1996 & 10.8 & 3.9 \\
\hline \multicolumn{4}{|c|}{ DEVELOPING COUNTRIES } \\
\hline \multirow[t]{2}{*}{ Brazil } & 1987 & 24.3 & 16.2 \\
\hline & 1995 & 13.4 & 3.5 \\
\hline \multirow[t]{2}{*}{ China } & 1987 & NA & 0.2 \\
\hline & 1997 & NA & 4.1 \\
\hline \multirow[t]{2}{*}{ Hong Kong } & 1985 & 10.2 & NA \\
\hline & 1994 & 16 & 12.8 \\
\hline \multirow[t]{2}{*}{ Indonesia } & 1992 & 3.3 & 0.5 \\
\hline & 1996 & 4.7 & 0.9 \\
\hline \multirow[t]{2}{*}{ Malaysia } & 1985 & 29.8 & NA \\
\hline & 1994 & 43.7 & NA \\
\hline \multirow[t]{2}{*}{ Mexico } & 1985 & 42.7 & NA \\
\hline & 1993 & 17.9 & 3.3 \\
\hline Nepal & 1998 & 1.9 & NA \\
\hline Singapore & 1980 & 15.3 & NA \\
\hline
\end{tabular}

In addition, MNEs tend to have two characteristics that make them stand out. First, MNEs have been found to be concentrated in the more “dynamic” sectors of the economy (Harrison, 1999). Thus, as Table B4.2 shows, even though they play a relatively small role in most economies in terms of level of total employment, MNEs 
often play a disproportionately large role in two very different types of industrial sectors. On the one hand, they tend to be in the more competitive or dynamic sectors typified by high growth rates and the use of new and emerging technologies (e.g., electronics, communication equipment, and industrial machinery). On the other hand, MNEs tend to dominate in mature sectors where economies of scale, branding and advertising determine market share (e.g., petroleum products, chemicals, automobiles, food and beverages and consumer goods) In such sectors, while the technology underlying these industries may be diffused and codified, capital limitations and marketing capabilities have meant that just a few MNEs maintain a large share of the global market.

The second reason MNE activity has significant policy implications is that the share of MNEs in both types of industrial sectors have been seen to be increasing, largely due to the policies associated with the Washington Consensus. The increased role of MNEs in certain sectors is in part a result of aggressive liberalization of FDI regimes and privatization programmes. Indeed, the greatest change has been the reduction in state ownership and the subsequent privatization of assets.

The growth of MNEs and their dominance of certain sectors are often associated with their pre-eminent position in the creation and ownership of technological assets. That both developing and developed countries alike can benefit from spillovers accruing from MNE activity is not disputed, as these assets are proprietary and are not easily duplicated. However, it remains an assumption that MNE activity is a sine qua non for economic development, and that greater FDI flows will automatically result in the dissemination of these technologies and organizational practices among countries and specially, from developed to developing countries.

Source: Adapted from Narula and Marin (2003) 


\section{Relating absorptive capacity to employment growth}

As we have highlighted above, absorptive capacity determines the extent to which economic actors in a given location are able to internalize spillovers efficiently and this, in turn, determines productivity growth, which in turn affects economic growth. The relationship of absorptive capacity to employment, on the other hand is less clear. There are three ways in which we can examine the employment effects of increased absorptive and technological capacity.

First, there are those effects that can be classified as first-degree effects, because (as Box 3.3 clearly highlights) one of the primary components of absorptive capacity is human capital. Thus, by its very nature, increases in absorptive capacity imply an increase in the quality (but not necessarily the quantity) of employment. Likewise, simply increasing the provision of education and training - be it at firm level or through "general" secondary and tertiary education - leads immediately to increases in absorptive capacity. However, while such developments certainly increase the employability of the workforce, and also increase the attractiveness of a location for firms that seek to internalize these potentially employable people, it does not imply that such first-degree effects influence growth per se, or indeed act to reduce poverty in any way. Indeed, unemployment may be as high, with the only difference being that the unemployed are simply more highly skilled.

Second, one can enquire about the second-degree effects. In other words, what is the influence on employment from increased absorptive capacity, when combined with technology flows - as in increased technological capability and productivity. This is perhaps where the role of absorptive capacity can be properly appreciated.

According to neoclassical theory, a country’s productivity growth comes from labour growth and capital accumulation. Mainstream economic literature has generally argued that productivity growth is positively associated with employment growth (see Spiezia and Vivarelli (2002), and Pianta (2004) for a review of this literature). At the risk of oversimplification, this view is predicated on the assumption that compensation mechanisms exist which create new jobs, compensating for the reduction in jobs due to 
productivity improvements stemming from innovations. This view has been controversial since the time of Ricardo and Marx. The evidence for and against the nature and efficiency of these compensatory mechanisms has continued to pile up, with debate between the various schools of thought focusing on the issue of whether stable product and labour market equilibria exist or not.

Disequilibrium perspectives (which include evolutionary and neo-schumpeterians, as well as regulationists) argue that innovation both creates and destroys jobs, such that the net amount may be either positive or negative, and that this imbalance may not be transitional. Jobs lost and jobs created may take place in different sectors or require different skills, resulting in both frictional and structural unemployment which (contrary to the view taken by mainstream economics) may not be a temporary phenomenon. Sustainable aggregate growth only occurs once these mismatches between the new and old technologies and their associated economic and social structures and institutions are subsumed.

In general, the evidence does seem to point to the fact that the rate of technological change, the technological characteristics of the industry, and the nature of innovation in any given industry fundamentally affect the efficacy of the compensatory mechanisms, and influence the quality and quantity of employment differently (Pianta 2000, 2004). Despite differences of opinion with regards the relationship between productivity and employment, it is largely uncontroversial that absorptive capacity plus technology flows generally result in innovation, upgrading and productivity growth which ceteris paribus increase the demand for skilled labour.

Thus, technology flows contribute to the generation of employment in a country, which is to say they increase the employment level quantitatively. At the same time, investments can also cause direct increases in the quality of the domestic workforce, by providing formal and informal training, as well as through the process of learning-bydoing, as a means to transfer superior technological knowledge to domestic employees.

Potentially positive human capital externalities can occur through indirect means, also both quantitatively and qualitatively. On a quantitative level, this may happen because suppliers and customers are expected to increase their own employment as a direct consequence of the increased economic activity due to the firm's participation in 
the economy. On a qualitative level, human capital externalities can occur firstly because affiliates are expected to provide training and technical assistance to suppliers and, secondly, because firms are expected to have access to a more productive pool of potential employees who have been trained by MNE affiliates in newer and more productive technologies. 


\section{Economic development and the role of absorptive capacity}

In this section we examine how absorptive capacity changes with stages of economic development as well as the importance of the different aspects of absorptive capacity at different stages. Following Criscuolo and Narula (2002) we stipulate the existence of four stages of economic development in terms of ability to accumulate knowledge as follows: the pre catching-up stage, the catching-up stage, the pre frontier-sharing stage and the frontier-sharing stage. Some general characteristics of countries in each stage are presented in Table 6.1.

Absorptive capacity and technological accumulation are concatenated and interdependent: increases in absorptive capacity ceteris paribus support further technological accumulation, that itself supports further development of absorptive capacity. It is worth noting that absorptive capacity and technology accumulation can be a virtuous and self-reinforcing process, although not necessarily so. Depending on their distance from the frontier, different countries adopt different modalities in accumulating technology (see Table 6.1).

National absorptive capacity is taken to be a function of the distance from the technological frontier, which is defined as the difference in knowledge stocks at the country level and at the frontier. Ceteris paribus, for any given level of absorptive capacity, the farther from the frontier a country is, the easier it would be to assimilate foreign knowledge. The distance to frontier is taken not only as a measure of technological complexity but also of a country's efficiency in exploiting available knowledge in the innovation and production system. Given the increased complexity of knowledge as a country approaches the technological frontier, the relationship between its absorptive capacity and the stages of development would not be a linear one, as suggested in Figure 6.1.

Figure 6.1 also illustrates the dynamics of the absorptive capacity relative to time.

Once the country has reached the threshold level of knowledge base, absorptive capacity rapidly increases. It reaches a maximum when the country achieves an intermediate level of development and foreign technology is more technologically congruent. As the 
Table 6.1 Stages of absorptive capacities

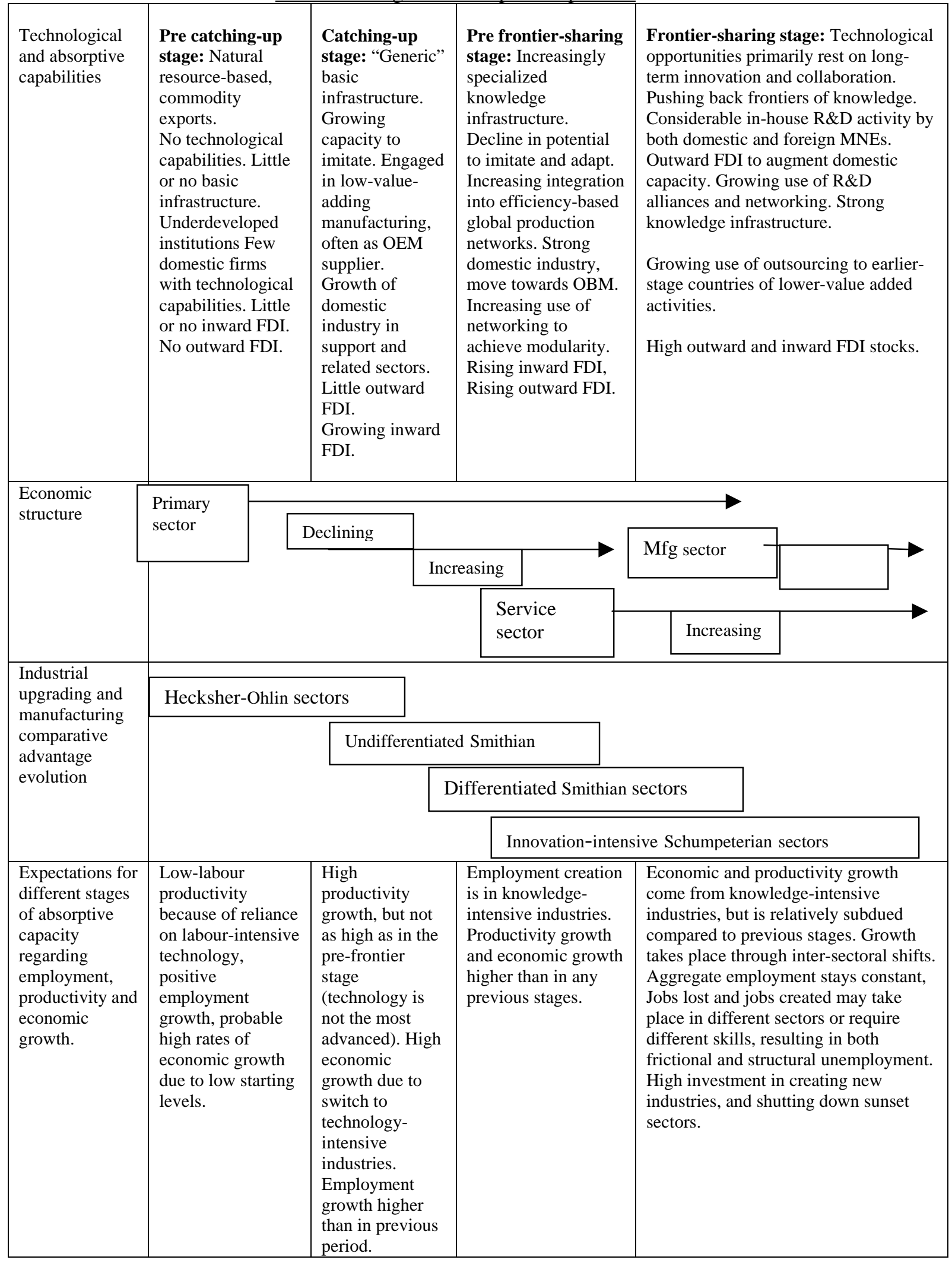


country approaches the frontier, absorptive capacity declines both because the knowledge available to be assimilated is smaller and the complexity involved in its exploitation is higher. Note that regardless of whether we use a fixed or moving frontier, absorptive capacity will tend to zero as the country approaches the frontier, as Figure 6.1 shows. However, the capability to absorb reaches a maximum at the frontier, and may be said to be monotonically related to knowledge accumulation as in Figure 6.2. In other words, at the frontier, it is theoretically possible to absorb more knowledge, since the capability to absorb can only increase with knowledge accumulation, but absorptive capacity is an inverse function of the available unlearned knowledge. 
Figure 6.1: The non-linear relationship between absorptive capacity and the technological gap
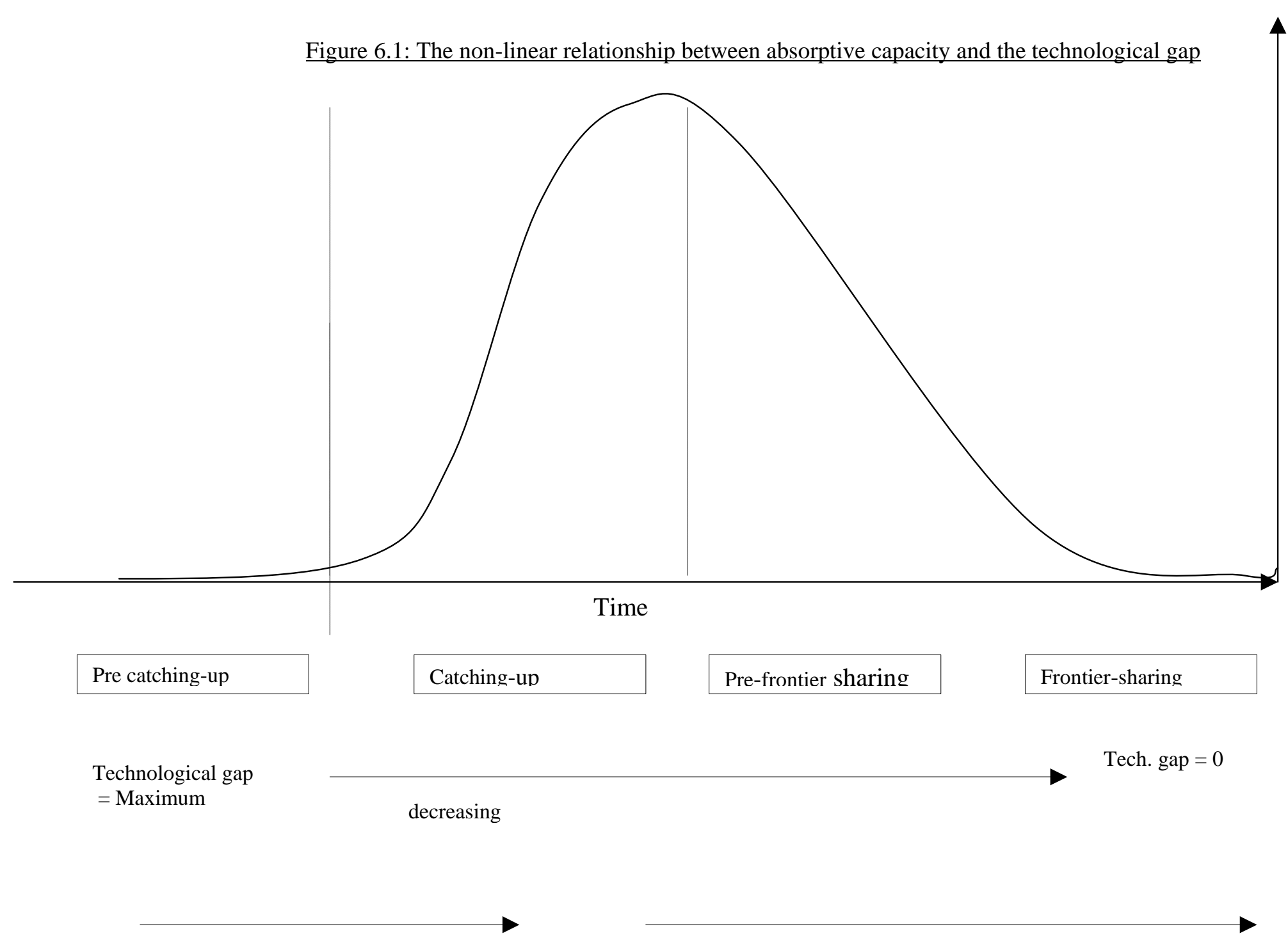


\section{Pre-catching-up stage}

As shown in Figure 6.2, the technology accumulation process starts at a very low rate until a minimum (and threshold-) level of knowledge accumulation is achieved. This is identified as the pre-catching-up phase. At this lower extremity, a minimum level of absorptive capacity is necessary for domestic firms to be able to interpret and internalize technology efficiently. The existence of these threshold effects has been reported in empirical analysis on FDI and trade-related R\&D spillovers. As Findlay (1978) and Perez and Soete (1988) among others have stressed, a minimum level of scientific and technical knowledge is required for using innovation, below which the cost of adoption can be prohibitive. It should be noted that entry barriers are always high at any point along the life cycle: a minimum level of appropriate skills and experience are still required for the imitation of a particular innovation even in its mature phase. Besides, it is worth noting that even where a product or technology is mature, there may be a very high level of complexity in the integration of its constituent technologies or modules (James and Romijn 1997).

Pre-catching-up countries are often resource-based economies: their economy is supported mainly through the production of some primary, natural resource based industry such as agriculture, petroleum or other extractive industry (see Table 6.1). In certain cases, the resource may simply be unskilled labour. As Table 6.2 indicates, even basic infrastructure at this stage is rudimentary, often unable to support even the primary sector. For instance, electricity consumption and telephone lines are 8 per cent and 9 per cent of the level of the frontier countries. Most industrial sectors are nonexistent. It is for this reason that inward technology flows though FDI will be low, as the locational advantages of the country are insufficient to offset the cost of effectively exploiting the factor conditions, given the lack of support and related industry. Government involvement (in the form of state subsidies and parastatals) will be high as a percentage of total economic activity, although small in absolute terms, since income levels are low. In other words, market imperfections will have to be addressed by governments, through the development of basic infrastructure as well as the fostering of support industries (such as banking). Accumulated technology will be low, as domestic 
firms are either non-existent or government-owned or subsidized. They rely heavily on foreign technology and know-how, largely acquired through licensing (or simply by copying) but most often are just embodied in imports. Depending on the ability of the government to take measures to prevent a balance of trade deficit, as well as developing avenues to encourage investment and improve infrastructure, it may be possible to shift the technological accumulation rate by fostering innovation and the acquisition of more productive equipment - thereby increasing the technological accumulation of domestic firms. As Table 6.3 suggests, countries at the pre-catching up stage possess few technological capacities. During this stage, they attempt to develop a minimum threshold level of absorptive capacity necessary to absorb foreign knowledge available, largely in the form of "generic" infrastructure. Little, if any, formal or informal R\&D activity is carried out. Knowledge is accumulated mainly through learning-by-doing. The focus of policy-makers is to create basic infrastructure and any and all flow/s of technology have a positive impact on technology accumulation, as well as positive influences on the growth of both quality and quantity of employment. Table 6.4 shows the considerable weakness in civil institutions. Apart from building up basic infrastructure, the other most important priority is associated with creating the appropriate formal and informal institutions. 
Figure 6.2: Changes in knowledge accumulation over time: Dual asymptotes

Knowledge accumulation

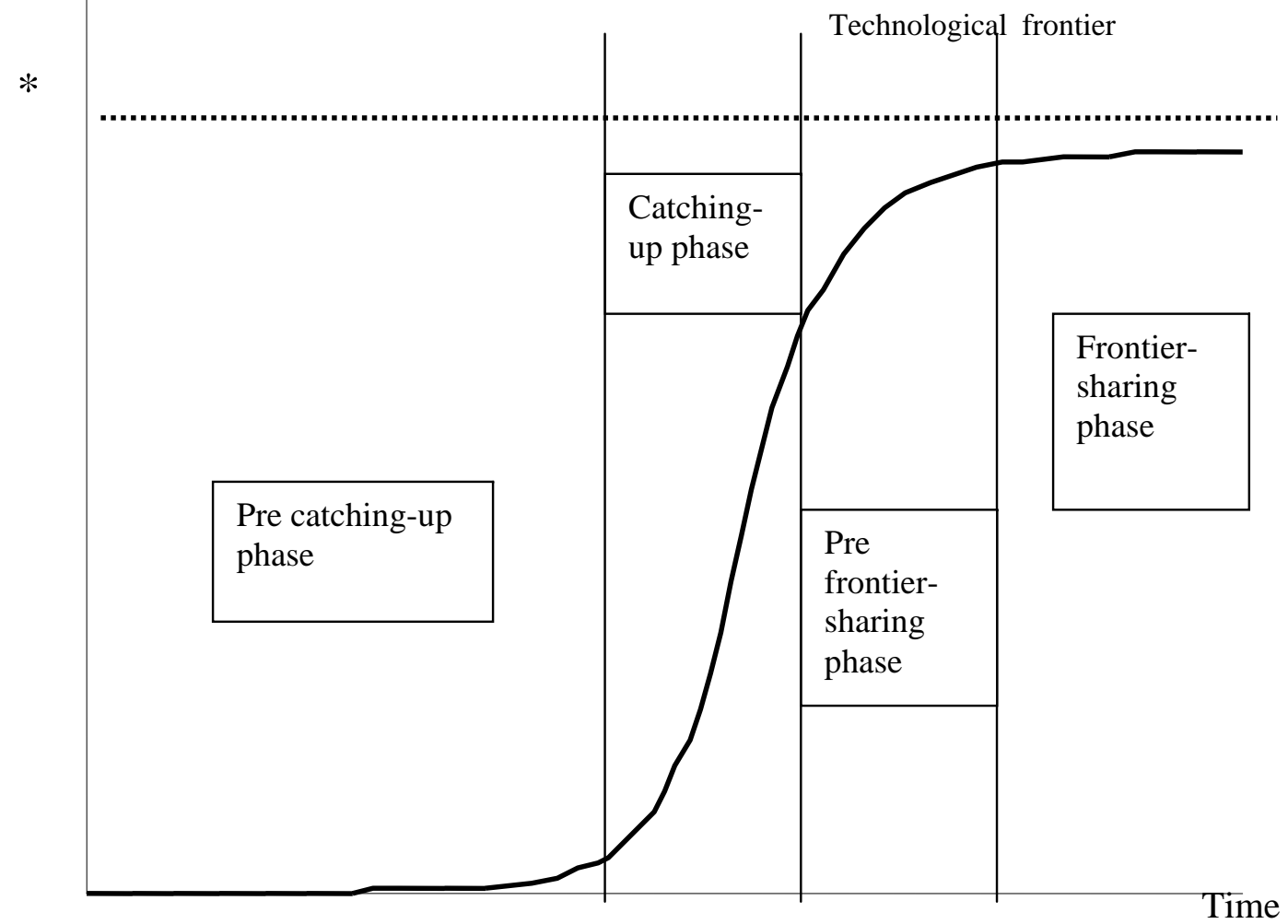


Table 6.2: Indicators of basic infrastructure

\begin{tabular}{|c|c|c|c|c|c|c|c|c|}
\hline & $\begin{array}{c}\text { Electric power } \\
\text { consumption } \\
\text { (kwh per capita) }\end{array}$ & $\begin{array}{c}\text { Health expenditure } \\
\text { per capita } \\
\text { (current US\$) }\end{array}$ & $\begin{array}{c}\text { Hospital } \\
\text { beds } \\
\text { (per } 1000 \text { people) }\end{array}$ & $\begin{array}{c}\text { Rail } \\
\text { lines } \\
\text { (total km) }\end{array}$ & $\begin{array}{c}\text { Roads } \\
\text { paved } \\
\text { (\%total roads) }\end{array}$ & $\begin{array}{c}\text { Telephone } \\
\text { mainlines } \\
\text { (per } 1000 \text { people) }\end{array}$ & $\begin{array}{l}\text { School } \\
\text { enrolment } \\
\text { primary }\end{array}$ & $\begin{array}{c}\text { School } \\
\text { enrolment } \\
\text { secondary }\end{array}$ \\
\hline Pre catching-up & & & & & & & (\% gross) & (\% gross) \\
\hline Peru & 610 & 104 & 1 & 1691 & 12 & 64 & 124 & 74 \\
\hline Mexico & 1482 & 234 & 1 & 17697 & 32 & 108 & 114 & 68 \\
\hline Venezuela & 2553 & 181 & 1 & 336 & 34 & 112 & 97 & 52 \\
\hline Nigeria & 83 & 7 & NA & 3557 & 25 & 4 & 87 & 31 \\
\hline Pakistan & 341 & 18 & NA & 7791 & 44 & 20 & 71 & 25 \\
\hline Viet Nam & 217 & 16 & 2 & 3142 & 25 & 23 & 112 & 56 \\
\hline Average & 881 & 93.33 & 1 & 5702.33 & 28.67 & 55.17 & 100.83 & 51.00 \\
\hline As $\%$ of frontier & $8 \%$ & $4 \%$ & $12 \%$ & $16 \%$ & $34 \%$ & $9 \%$ & $97 \%$ & $43 \%$ \\
\hline \multicolumn{9}{|l|}{ Catching-up } \\
\hline China & 722 & 34 & 2 & 58656 & 22 & 77 & 115 & 65 \\
\hline India & 349 & 22 & NA & 62759 & 52 & 24 & 99 & 46 \\
\hline Malaysia & 2341 & 100 & 2 & 1622 & 74 & 191 & 102 & 64 \\
\hline Brazil & 1750 & 317 & 3 & 25652 & 8 & 136 & 132 & 78 \\
\hline Argentina & 1817 & 640 & 3 & 28291 & 29 & 197 & 112 & 85 \\
\hline Chile & 2058 & 340 & 3 & 4184 & 17 & 189 & 101 & 72 \\
\hline Average & 1506.17 & 242.17 & 2.60 & 30194.00 & 33.67 & 135.67 & 110.17 & 68.33 \\
\hline As $\%$ of frontier & $14 \%$ & $9 \%$ & $32 \%$ & $84 \%$ & $40 \%$ & $22 \%$ & $106 \%$ & $58 \%$ \\
\hline \multicolumn{9}{|l|}{ Pre-frontier } \\
\hline Korea & 4793 & 503 & 5 & 3123 & 73 & 445 & 96 & 100 \\
\hline Singapore & 6277 & 879 & NA & NA & 98 & 456 & 95 & 74 \\
\hline Hong Kong & 5128 & NA & NA & NA & 100 & 564 & 94 & 73 \\
\hline Average & 5399.33 & 691.00 & 5.00 & 3123.00 & 90.33 & 488.33 & 95.00 & 82.33 \\
\hline As $\%$ of frontier & $51 \%$ & $27 \%$ & $61 \%$ & $9 \%$ & $108 \%$ & $80 \%$ & $92 \%$ & $69 \%$ \\
\hline Frontier-sharing & 15293 & 1892 & 5 & 39400 & NA & 642 & 100 & 105 \\
\hline US & 11863 & 4017 & 4 & 160000 & 60 & 648 & 101 & 97 \\
\hline Japan & 7272 & 2627 & 16 & 20165 & 70 & 542 & 101 & 104 \\
\hline Denmark & 6041 & 2732 & 5 & 2047 & 100 & 663 & 102 & 124 \\
\hline Germany & 5681 & 2842 & 10 & 36652 & 99 & 571 & 104 & 102 \\
\hline Netherlands & 5786 & 2070 & 11 & 2902 & 90 & 581 & 108 & 130 \\
\hline Norway & 24010 & 2846 & 15 & NA & 75 & 607 & 101 & 117 \\
\hline Sweden & 14261 & 2558 & 4 & 10068 & 77 & 698 & 108 & 149 \\
\hline UK & 5351 & 1577 & 4 & 17067 & 100 & 552 & 108 & 140 \\
\hline Average & 10617.56 & 2573.44 & 8.22 & 36037.63 & 83.88 & 611.56 & 103.67 & 118.67 \\
\hline As $\%$ of frontier & $100 \%$ & $100 \%$ & $100 \%$ & $100 \%$ & $100 \%$ & $100 \%$ & $100 \%$ & $100 \%$ \\
\hline
\end{tabular}




\section{Catching-up stage}

While acquiring this threshold level of absorptive capacity occurs in the pre catching-up stage, catching-up countries will have achieved the necessary threshold level of technological capacity (see Figure 6.1), as indicated by the presence of basic infrastructure, some level of knowledge infrastructure and a certain domestic industrial capacity. Examples are China, India, Malaysia, Brazil, Chile and Argentina (see Table 6.2).

Such countries are able to benefit from the virtuous circle of technology accumulation occurring in the catching up stage. The catching-up stage is characterized by high rates of accumulation and absorption of foreign knowledge, which in itself leads to further development of absorptive capacities. During this stage, knowledge is accumulated through assimilation of spillovers originated from trade and/or inward FDI (Table 6.1).

Depending on the ability of the government to attract and encourage investment and to improve advanced infrastructure (such as universities, the provision of scientists and engineers) it may be possible to shift the technological accumulation rate by fostering innovation and the acquisition of more productive equipment - thereby increasing the ownership advantages of domestic firms in manufacturing industries. During the catching-up phase, comparative advantage will shift firstly from Hecksher-Ohlin industries to undifferentiated Smithian and later to differentiated Smithian sectors (Table 6.1). The economy will continue to have a considerable amount of government influence, particularly in the provision of public and quasi-public goods. Due to rising incomes, the quantity of demand is bound to rise and with it the opportunity for making above-normal profits. This will result in an increase in firm rivalry and, consequently, innovation. Licensing of technologies and other arms-length acquisition of technologies will continue to occur, although inward FDI will increasingly be used as MNEs seek to take advantage of the growing significance of the market. Inward FDI will affect growth of related and support industries as it acquires intermediate goods locally (backward integration), developing technological advantages and spurring innovation (innovation will primarily be of an applied nature, typically product modification). Nonetheless, at the early stages 
of catching-up little formal R\&D activity is carried out and knowledge is accumulated mainly through informal technology creation, particularly through reverse engineering. However, the formal aspect of R\&D increases towards the end of the catching-up phase.

The existence of a certain level of absorptive capacity determines the ability of an economic unit to accumulate additional technological knowledge, and such technological advances themselves support the further development of absorptive capacity in a cumulative and interactive process (Table 6.3). Knowledge accumulation is much more rapid once the initial threshold level of absorptive capacity exists (Figure 6.2). Simply put, technology absorption is easier, once they have 'learned-to-learn'. Furthermore, a large potential pool of "mature" technologies exists which may be imitated.

It is important to note that while technological accumulation increases rapidly during this phase (as shown in Figure 6.2), absorptive capacity actually peaks (Figure 6.1), and then begins to decline. Countries must have the capacity not just to absorb and imitate technological development created by others, but also the ability to generate inventions of their own. This requires technological capabilities that are non-imitative. In other words, learning-by-doing and learning-by-using have decreasing returns as one approaches the frontier, and in-house learning and learning-by-alliances become more efficient options. 
Table 6.3: indicators of advanced infrastructure

\begin{tabular}{|c|c|c|c|c|c|c|}
\hline & $\begin{array}{c}\text { School } \\
\text { enrolment } \\
\text { tertiary } \\
\text { (\% gross) }\end{array}$ & $\begin{array}{c}\text { Scientists and } \\
\text { engineers } \\
\text { (per million people) }\end{array}$ & $\begin{array}{l}\text { Public spending } \\
\text { on education } \\
\text { (\% of GDP) }\end{array}$ & $\begin{array}{c}\text { Subsidies and } \\
\text { other transfers } \\
\text { (\% of expenditure) }\end{array}$ & $\begin{array}{c}\text { Tax } \\
\text { revenue } \\
(\% \text { of } \mathrm{GDP})\end{array}$ & $\begin{array}{c}\text { Highest } \\
\text { marginal tax rate } \\
\text { corporate }\end{array}$ \\
\hline \multicolumn{7}{|l|}{ Pre catching-up } \\
\hline Peru & 27.00 & 230.00 & 3.00 & 33.00 & 14.00 & 30.00 \\
\hline Mexico & 18.00 & 232.00 & 4.00 & 47.00 & 13.00 & 35.00 \\
\hline Venezuela & 28.00 & 192.00 & n.a. & n.a. & 14.00 & 34.00 \\
\hline Nigeria & 4.00 & n.a. & n.a. & n.a. & n.a. & 30.00 \\
\hline Pakistan & 4.00 & n.a. & 3.00 & 15.00 & 13.00 & n.a. \\
\hline Viet Nam & 8.00 & n.a. & 3.00 & 43.00 & 17.00 & 32.00 \\
\hline Average & 14.83 & 218.00 & 3.25 & 34.50 & 14.20 & 32.20 \\
\hline As $\%$ of frontier & $26 \%$ & $6 \%$ & $55 \%$ & $53 \%$ & $47 \%$ & $104 \%$ \\
\hline \multicolumn{7}{|l|}{ Catching-up } \\
\hline China & 6.00 & 473.00 & 3.00 & n.a. & 6.00 & 30.00 \\
\hline India & 8.00 & 157.00 & 3.00 & 40.00 & 9.00 & 40.00 \\
\hline Malaysia & 17.00 & 130.00 & 5.00 & 23.00 & 20.00 & 28.00 \\
\hline Brazil & 15.00 & 246.00 & 5.00 & 61.00 & 20.00 & 15.00 \\
\hline Argentina & 43.00 & 695.00 & 4.00 & 57.00 & 12.00 & 35.00 \\
\hline Chile & 33.00 & 361.00 & 4.00 & 54.00 & 18.00 & 15.00 \\
\hline Average & 20.33 & 343.67 & 4.00 & 47.00 & 14.17 & 27.17 \\
\hline As $\%$ of frontier & $35 \%$ & $10 \%$ & $68 \%$ & $73 \%$ & $47 \%$ & $88 \%$ \\
\hline \multicolumn{7}{|l|}{ Pre-frontier } \\
\hline Korea & 66.00 & 2'160.00 & 4.00 & 49.00 & 17.00 & 28.00 \\
\hline Singapore & 41.00 & 2'957.00 & 4.00 & 16.00 & 16.00 & 26.00 \\
\hline Hong Kong & 26.00 & n.a. & n.a. & n.a. & n.a. & 16.00 \\
\hline Average & 44.33 & 2'558.50 & 4.00 & 32.50 & 16.50 & 23.33 \\
\hline As $\%$ of frontier & $76 \%$ & $73 \%$ & $68 \%$ & $50 \%$ & $55 \%$ & $75 \%$ \\
\hline \multicolumn{7}{|l|}{ Frontier } \\
\hline Canada & 75.00 & 3'059.00 & 6.00 & 65.00 & 20.00 & 38.00 \\
\hline US & 76.00 & 3'912.00 & 5.00 & 61.00 & 19.00 & 35.00 \\
\hline Japan & 45.00 & 5'196.00 & 4.00 & n.a. & n.a. & 30.00 \\
\hline Denmark & 52.00 & 3'332.00 & 8.00 & 64.00 & 33.00 & 30.00 \\
\hline Germany & 47.00 & 2'898.00 & 5.00 & 58.00 & 27.00 & 25.00 \\
\hline Netherlands & 50.00 & $2 ' 437.00$ & 5.00 & 71.00 & 41.00 & 35.00 \\
\hline Norway & 65.00 & 3'979.00 & 7.00 & 70.00 & 33.00 & 28.00 \\
\hline Sweden & 58.00 & $4^{\prime} 137.00$ & 8.00 & 69.00 & 34.00 & 28.00 \\
\hline UK & 54.00 & $2^{\prime} 484.00$ & 5.00 & 58.00 & 33.00 & 30.00 \\
\hline Average & 58.00 & $3 ' 492.67$ & 5.89 & 64.50 & 30.00 & 31.00 \\
\hline
\end{tabular}


Table 6.4: Indicators of formal and informal institutions

\begin{tabular}{|c|c|c|c|c|c|c|c|}
\hline & $\begin{array}{l}\text { Corruption } \\
\text { Index } 2002\end{array}$ & $\begin{array}{c}\text { Civil } \\
\text { liberties }\end{array}$ & $\begin{array}{l}\text { Total } \\
\text { scientific } \\
\text { articles }\end{array}$ & $\begin{array}{l}\text { Internationally } \\
\text { authored } \\
\text { articles }\end{array}$ & $\begin{array}{l}\text { HDI } \\
2001\end{array}$ & $\begin{array}{c}\text { Internet } \\
\text { users } 2001 \\
\text { per } 100\end{array}$ & $\begin{array}{l}\text { Rule of } \\
\text { law* }^{*}\end{array}$ \\
\hline Peru & 4.00 & 3 & 119 & 105 & 0.75 & 7.70 & -0.53 \\
\hline Mexico & 3.60 & 2 & 3095 & 1418 & 0.80 & 3.60 & -0.41 \\
\hline Venezuela & 2.50 & 4 & 641 & 331 & 0.78 & 4.70 & -0.81 \\
\hline Nigeria & 1.60 & 5 & 477 & 149 & 0.46 & 0.10 & -1.13 \\
\hline Pakistan & 2.60 & 5 & 359 & 143 & 0.50 & 0.30 & -0.76 \\
\hline Viet Nam & 2.40 & 6 & 176 & 141 & 0.69 & 1.20 & -0.57 \\
\hline China & 3.50 & 6 & 13815 & 3962 & 0.72 & 2.60 & -0.19 \\
\hline India & 2.70 & 2 & 10272 & 1894 & 0.59 & 0.70 & 0.23 \\
\hline Malaysia & 4.90 & 5 & 618 & 344 & 0.79 & 27.30 & 0.34 \\
\hline Brazil & 4.00 & 3 & 6533 & 2501 & 0.78 & 4.70 & -0.26 \\
\hline Argentina & 2.80 & 3 & 2974 & 1120 & 0.85 & 10.10 & 0.22 \\
\hline Chile & 7.50 & 1 & 1263 & 659 & 0.83 & 20.10 & 1.19 \\
\hline Korea & 4.50 & 2 & 7772 & 2016 & 0.88 & 52.10 & 0.55 \\
\hline Singapore & 9.30 & 4 & 2022 & 678 & 0.88 & 41.20 & 1.85 \\
\hline Hong Kong & 8.20 & NA & 2393 & 1053 & 0.89 & 38.70 & 1.37 \\
\hline Canada & 9.00 & 1 & 24498 & 8665 & 0.94 & 46.70 & 1.70 \\
\hline US & 7.70 & 1 & 183906 & 39669 & 0.94 & 50.10 & 1.58 \\
\hline Japan & 7.10 & 2 & 52711 & 9275 & 0.93 & 38.40 & 1.59 \\
\hline Denmark & 9.50 & 1 & 5795 & 2813 & 0.93 & 42.90 & 1.71 \\
\hline Germany & 7.30 & 1 & 47714 & 18340 & 0.92 & 37.40 & 1.57 \\
\hline Netherlands & 9.00 & 1 & 13712 & 5654 & 0.94 & 49.10 & 1.58 \\
\hline Norway & 8.50 & 1 & 3542 & 1589 & 0.94 & 46.40 & 1.83 \\
\hline Sweden & 9.30 & 1 & 11093 & 4887 & 0.94 & 51.60 & 1.70 \\
\hline UK & 8.70 & 1 & 49221 & 16806 & 0.93 & 33.00 & 1.61 \\
\hline \multicolumn{8}{|c|}{$\begin{array}{l}\text { CPI Score from www.transparency.org. } \\
\text { CPI reflects the level of corruption in the public sector as perceived by business people. } \\
\text { Civil Liberties from Freedom House. } \\
\text { Total Scientific Articles and Internationally Authored Articles from Science and Engineering Indicators } \\
\text { HDI is the Human Development Index. Source: Human Development Report } 2003 .\end{array}$} \\
\hline \multicolumn{8}{|c|}{$\begin{array}{l}\text { * 'Rule of law' includes several indicators that measure the extent to which agents have confidence in the } \\
\text { rules of society on a scale of }-2.5 \text { to }+2.5 \text {. These include perceptions of the incidence of both violent and } \\
\text { non-violent crime, the effectiveness and predictability of the judiciary, and the enforceability of contracts. } \\
\text { Source: Kaufman, Kray and Zoido-Lobaton (2002), World Bank Policy Research Department Working }\end{array}$} \\
\hline
\end{tabular}




\section{Pre-frontier and frontier-sharing stage}

Pre-frontier-sharing countries are in the process of converging on the frontier, mainly the so-called Asian NICs, including Korea and Taiwan (China). We differentiate these from frontier-sharing countries, which are at or close to the frontier (the European Union, Japan, the United States). As any given country approaches the technological frontier, the accumulation process proceeds at a slower pace ('the pre frontier-sharing' stage). The assimilation of external knowledge becomes harder, both because of the increasing complexity and the quantity of knowledge, and the difficulties of acquiring this knowledge. Firms at the technological frontier are unwilling to sell state-of-the-art technologies to potential competitors, at least through arms-length transactions. Firms seeking access to newer technologies often resort to cooperative strategies such as joint ventures and $R \& D$ alliances, as markets for nascent and new technologies do not exist (Narula 2003a). For similar reasons, it has been argued that the threat of a high potential for imitation by host-country firms can influence the technological content of the capital goods imported by multinational affiliates (Glass and Saggi 1998).

As countries move closer to the frontier the absorptive capacity falls. This is because knowledge becomes more complex and tacit and thus more difficult to acquire, but also because there is less information to acquire. Figure 6.2 illustrates the inverse $\mathrm{U}$ relationship between the level of absorptive capacity and the stages of economic development. This complexity and uncertainty of knowledge closer to the frontier requires greater efforts on the part of firms, more resources devoted to it in the form of increased R\&D expenditure, more information and a knowledge base that goes beyond the national specialization. At these stages, knowledge accumulation occurs mainly through outward FDI-related R\&D, joint ventures and strategic alliances. The cost of imitation increases as the follower closes the gap with the leader and the number of technologies potentially available for imitation reduces. This implies that there are diminishing returns on marginal increases in absorptive capacity at the upper extreme, at the frontier-sharing stage (Criscuolo and Narula 2002). 
Although the country increasingly relies on internal R\&D since there is no longer the option to imitate the leader, it will actively engage in the exploitation of foreign knowledge sources through domestic $R \& D$, augmented with $R \& D$ undertaken in conjunction with outward FDI. At the same time, it will benefit from the assimilation and exploitation of the technological spillovers originating from the innovation activities that foreign affiliates carry out in the country. The increasing propensity among multinational firms from European countries, Japan and United States to locate their R\&D activity outside their home country reflects this strategy in the acquisition of technological spillovers. While in the catching-up phase the assimilation of spillovers relies on the activities of foreign firms and imports of intermediate goods, in the frontier-sharing phase - and sometimes even before this - firms adopt a more active learning strategy so as to gain access to external knowledge which could otherwise never be exploited.

Box 6.1 outlines the four main motives for investment and the embeddedness of MNEs that results from how firms tend to build incrementally on pre-existing locational advantages in a given host country.

Another aspect of advanced stages of development is that when a country approaches the frontier, it must be able not only to absorb and imitate technological developments but also to generate innovations of its own. Under these circumstances, strategies adopted at the catching-up stage have decreasing returns. In-house learning and learning-through-alliances are more efficient options. These arguments are illustrated by the case of Korea, as documented by Kim (1995) and Sachwald (2001). While in the catching-up stage, Korea used licensing and imports of capital goods as the primary way to acquire foreign knowledge - a strategy that exposed this country to second-best technologies. Although at present Korea is at the pre frontier-sharing stage in several sectors it is more inclined to absorb through imitation rather than in-house learning, as stressed for instance by Suh (2000). This situation, combined with the reluctance of industrialized countries to transfer advanced technology to Korea because of fear of loss of competitive advantage, has prompted Korea to emphasize technological capabilitybuilding and reverse technology transfer through outward FDI. 
Box 6.1 The quality of spillovers and the embeddedness of MNE affiliates

The embeddedness of MNEs is often (but not always) a function of how long they have been present, since firms tend to build incrementally. It is to be noted that firms build on location advantages that already exist in the host economy (Ritchie 2002), and increases in embeddedness are generally in response to improvements in the domestic technological and absorptive capacity.

Nonetheless, it is worth noting that there are probably many more instances where embeddedness, linkages and spillovers have not substantially increased over time. This reflects inter alia, the kind of subsidiaries, and motive of investment. The motive of an investment helps to determine (in conjunction with the host-country specific factors) the kind of MNE affiliate and therefore the potential for spillovers. It is generally acknowledged that there are four main motives for investment: 1) to seek natural resources; 2) to seek new markets; 3) to restructure existing foreign production through rationalization and 4) to seek strategically related created assets (Narula and Dunning 2000). These in turn can be broadly divided into two types. The first three represent motives which are primarily asset-exploiting in nature: that is, the investing company's primary purpose is to generate economic rent through the use of its existing firmspecific assets. The last is a case of asset-augmenting activity, whereby the firm wishes to acquire additional assets which protect or augment their existing created assets in some way. Indeed, the host country's location advantages play an important role in determining the level of embeddedness of the subsidiary, and this is the primary determinant of the quality of the FDI. This is for two reasons. First, the level of competence is a function of the quality of the location advantages that the host location can provide. High competence levels require complementary assets that are non-generic in nature, and are often associated with agglomeration effects, clusters, and the presence of highly specialized skills. In other words, firms are constrained in their choice of high competence subsidiaries by resource availability. For instance, R\&D activities tend to be concentrated in a few locations because the appropriate specialized resources are associated with a few specific locations. Second, MNEs have been shown to prefer to engage in sequential investment in locations that provide sub-optimal returns but with which they have prior experience, because firms are known to be boundedly rational. Furthermore, while the scope of activities undertaken by a subsidiary can be modified more or less instantly, developing competence levels takes time. MNE investments in high value-added activities (often associated with high competence levels) have the tendency to be "sticky". 


\section{Absorptive capacity and employment: Some policy issues}

The evidence on employment and innovation (see e.g., Spezia and Vivarelli (2002), Pianta (2004)) indicates that while innovatory activity and economic growth may well be highly interrelated phenomena, the link between innovation and employment is much more tenuous. Indeed, innovation and the adoption of new technologies can result not just in increased structural or frictional unemployment, but may well have longer term effects which include a reduction in the quantity and quality of employment. That is to say, net negative effects may occur which are not simply temporary disequilibria or transitory phenomenon. Increases in absorptive capacity do not always translate into positive economic development, or vice versa.

We have decomposed absorptive capacity into its constituent parts. As Section 3 illustrates, we need to separate absorptive capacity into four elements: firm-sector absorptive capacity, basic infrastructure, advanced infrastructure and formal and informal institutions. Each is equally indispensable on its own and has different costs and benefits at different stages. Increases in absorptive capacity at earlier stages of development are often associated with "generic" basic infrastructure and, by and large, increases in technological capacity have generally positive welfare effects. For example, increases in the percentage of population with primary and secondary education have numerous social and welfare benefits for society, as does the provision of infrastructure, such as roads, electricity and so forth. Investment in such resources have large multiplier effects since they contribute to so many facets of social, economic and human development. Indeed, their contribution to poverty reduction cannot be overstated.

It is in the provision of advanced infrastructure that the employment benefits can be ambiguous. First, because the provision of university graduates in science and technology are often under-utilized in pre catching-up and catching-up economies. The education systems are often copied from industrial countries, and provide skills which are of little immediate use. For example, scant R\&D and product design are being undertaken 
in most LDCs, so these engineers are often underemployed. As Oyelaran-Oyeyinka and Barclay (2003) point out in the case of Africa, despite the apparent shortage of skilled workers, a large proportion of the scientists and engineers tend to be employed in other capacities. They conclude that the education system in much of Africa reflects the colonial legacy (when the need was primarily for skilled administrators). The result in much of the developing world is that these scientists and engineers are part of the braindrain to the developed world where such skills are in demand.

Second, investments in specialized infrastructure for one sector are not necessarily applicable to another. Third, new technologies tend to be more efficient than the technologies they replace but also tend to use fewer human capital inputs. Thus, increased productivity may come at the expense of lower employment and therefore increased poverty. Fourth, new industries tend to replace old ones: resources invested in building a machine-tool industry tend to lead to a decline in the employment in the handicrafts sector.

However, this is a complex matter: the importance of advanced infrastructure is itself a stage-dependent phenomenon. Advanced infrastructure that may have been appropriate in a catching-up country provides greater employment effects in (say) Korea, than in (say) Peru. In other words, industrial development policy and investment in absorptive capacity has differing returns at different stages of development. It is important to underline the systemic nature of these different elements. For this reason, we emphasized the importance of formal and informal institutions. Systems - be they of innovation or of production - are not meant to imply a systematic organization of their constituent elements, but a systemic relationship between the various facets. To single out any one of these elements as being of exceptional importance is a commonplace error.

Institutions (in the sense of routines and procedures) create the milieu within which economic activity is undertaken. They establish the ground rules for interaction between the various economic actors and represent a sort of "culture". Institutions are both formal and informal, and will probably have taken years (if not decades) to create and sustain themselves. To modify and develop institutions is a complex and slow process, particularly since they cannot be created simply by government fiat. Their 
importance cannot be overemphasised, although much of the literature tends to pay scant attention to them, probably because they are hard to measure.

In essence, institutions underlay the cumulative causation of all elements within a system in the sense proposed by Myrdal (1957). As the data in Table 6.4 illustrates, issues such as the efficacy of the rule of law are crucial in bringing the various elements of absorptive capacity to work efficiently towards promoting economic development.

The cumulative causation principle also applies to policy. For example, firms must have access to skilled human capital if they are to create or absorb efficiently. It is no accident that firms often locate $R \& D$ facilities in physical proximity to locations with the best knowledge infrastructure. If (say) universities do not produce sufficient quantities of researchers at an internationally competent level, firms will locate their R\&D facilities elsewhere. But the systemic nature of policy means that if universities are to achieve this target, they need to have the financial and technical wherewithal to attract and retain the best scholars. Sustaining or strengthening firm-level innovatory capacity requires developing the capacity of the non-firm sector. Any industrial policy to build up competitiveness in a targeted sector without concerning itself with education policy is doomed to failure. Firms need to have the capacity to absorb and innovate, and this is embodied in people. Perhaps the single biggest determinant of India's successful software industry derives from its considerable investment in higher education. In addition to providing skilled labour, universities and other non-firm R\&D performers are an important source of knowledge for firms (Arundel and Geuna 2001).

The types of policy required at different stages of development are naturally different, but globalization has created "economic equity" in the sense that the challenges of developing countries are increasingly similar to those of developed countries. International competition means that all economic actors are forced to use similar technologies even though their comparative advantage is in labour rather than capital. This means that all countries must have access to the same new technologies and have the capacity to use them efficiently (Lall 2003b). At the same time, pre catching-up countries must also acquire expertise in older, "building-block" technologies that define the efficiency with which newer technologies can be used and integrated into goods and 
services. This situation presents the policy-maker in such developing countries with the dilemma of picking winners.

It was formerly the case that when the technological gap was large, countries generally started from a small employment base and followed a well-worn path in terms of picking technologies. The specialized skills and infrastructure required for these postparadigmatic, largely mature technologies are well known. Such technologies tend to be low skills- and labour-intensive, of which most countries at these stages have a surplus supply. However, in the globalized world of today, both developing and developed countries must pick more advanced technologies closer to the frontier - and it is here that the greatest risks arise.

Newer technologies are capital- rather than labour-intensive and, importantly, knowledge-intensive. Even more importantly, the kind of knowledge-intensity needed also tends to be capital-intensive. For example, producing skilled researchers in biotechnology requires millions of dollars of specialized equipment, and the academic and technical staff to run such a facility must be paid very large salaries, since their skills tend to be in high demand globally. Most developing countries cannot afford to invest such large sums in such seemingly "white elephant” projects, since capital is scarce, and such projects have an opportunity cost.. Moreover, simply producing sufficient scientists does not a biotechnology industry make. Such scientists often cannot find employment domestically and - as is the case with many skilled scientists in developing countries part of them brain-drain to the European Union and the United States. ${ }^{9}$

At first glance, the benefits of pursuing knowledge-intensive technologies in which developing countries have neither the appropriate comparative advantage, nor the human or physical capital to devote to such projects, seems rather ambiguous. Nonetheless, developing countries often seek to leapfrog so as to avoid dependence on obsolete or low-tech technologies, since such products tend to be priced as commodities. It is therefore hard to argue against some level of such investment, especially as

\footnotetext{
${ }^{9}$ Well over 50 per cent of all American $\mathrm{PhD}$ candidates in science and engineering are foreign-born, with a considerable share having had their undergraduate training in developing countries. A good percentage eventually stay on in the United States.
} 
exceptions such as India's software industry have suggested that opportunities to leapfrog do exist.

\section{Box 7.1 Not relying on FDI as a means to improve human capital}

The Washington Consensus has - perhaps unintentionally - resulted in policy-makers erroneously thinking that MNEs can substitute for the public provision of education and training. However, MNEs are unwitting development tools: few consider their main aim as improving national economies. Their primary objective is to generate profits. MNEs do not provide training and other opportunities for human capital development because they are philanthropic; they do so because they need to do so to optimize their profitmaking potential (Kapstein 2002, Slaughter 2002).

MNEs seek to optimize their return on investment and this logically requires that they minimize their costs. By definition, any investment in human capital development is an additional cost. When MNEs find that they have to provide basic education and skills to their workers - what should ordinarily be a public good (a case of hierarchies having to overcome government failure) - they are less inclined to invest. MNEs do not do so lightly, or without consideration of the benefits. MNEs are creatures of the market par excellence, responding efficiently to supply and demand conditions, and changes in these. They do not make such investments unless there is an opportunity for rentseeking.

Governments are at fault for assuming that FDI will substitute for domestic investment - whether in the form of policies to promote linkages, to encourage the development of domestic firms, or the development of important infrastructure and the maintenance of essential non-firm sector activities which provide the raw material for absorptive capacity.

It is important to emphasize the limited resources of developing countries, and the increasing risks of technological competitiveness closer to the frontier. Almost every country has, during the last decade of the twentieth century, invested large sums in creating absorptive capacity in ICTs, and the industrial landscape of most countries (developed and developing) is littered with the remnants of failed ICT industries. While 
catching-up 'rich' countries such as Greece, Norway or Portugal may be able to bear the brunt of such failures, developing countries cannot. Despite this, poorer governments continue to subsidize such industries. Sometimes this is part of a strategy to create viable new competitive sectors, but very often political and systemic inertia prevents withdrawing. Exiting from failed or sunset industries requires considerable political and economic finesse (Narula 2003a). The fact remains that it is very difficult to differentiate ex ante between failed uncompetitive sectors in sunset sectors and those that have potential but still need fostering. In many instances, economies are increasingly relying on MNEs to 'kick start' uncompetitive domestic industries, but this is not always a successful option. Box 7.1 looks at the role MNE plays in improving national economies and underlines the necessity for policy-makers to opt for a combination of low and hitech strategies.

Even where resources and lock-in are not an issue, increases in absorptive capacity close to the frontier do not necessarily result in increases in employment. Per definition, new technologies often replace old technologies, and they are often less labour-intensive and more capital-intensive.

In pursuing a combined simultaneous strategy of low and hi-tech industrial upgrading, it seems clear that a careful selection policy needs to be implemented, and this selection must itself be selective if efficient allocation is to be ensured (Lall 2003b).

Selecting sectors is a task fraught with pitfalls, not least because selecting the "right" industry to target becomes more difficult the closer the country is to the technological frontier. When governments attempt to select preferred industries in which to focus some distance away from the technological frontier, the direction in which investment is to be made is fairly obvious since firms at the frontier (i.e., the technology leaders) have already done so in the past. That is to say, the further a country is from the technological frontier, the easier it is to 'pick' industries that will be successful. The relative success of MITI in picking winners in the 1950s and 1960s, and their subsequent less successful interventions in the 1980s and 1990s well illustrates this point. Although there is a danger in investing limited resources in niche sectors which become obsolete, or get replaced by a new technological paradigm, this need not happen if broader sectors 
are targeted that are complementary to, and help upgrade, existing competencies and skills.

The role of governments in improving the quality of human capital cannot be over-emphasized. Qualified human resources are essential in monitoring the evolution of external knowledge and in evaluating their relevance, and for the integration of these technologies into productive activities. Human capital represents an important subset of absorptive capabilities, and this is well acknowledged by policy makers everywhere.

However, the presence of a highly skilled labour force is not a sine qua non for improved innovativeness, although it is certainly a necessary condition. Simply providing tertiary level education, and skilled manpower does not lead to increased $R \& D$, nor is there a direct connection between and education and technological competence. The availability of a large stock of suitably qualified workers does not in itself result in efficient absorption of knowledge, as is well illustrated by the former centrally planned economies of Eastern Europe. But quality of the training and the ability of industry to exploit available skills in R\&D or other technical effort matter a great deal.

The importance of education policy as a fundamental condition for technological competitiveness and industrial development should by now be seen to be axiomatic. This has been emphasized by almost every major international organization and academic institution. I will not berate this point at any length here, but simply emphasize a related point, that while the provision of high quality education and the improvement of human capital represents a core aspect of absorptive capacity, its presence per se is not a sine qua non for knowledge accumulation. While both physical and human capital are necessary inputs for industrial development, the lack of appropriate incentives for production and investment can compromise the success of the technological upgrading (Lall, 1992). The most significant lesson provided in this study is that the governments cannot and should not view their employment and technological agendas individually. Likewise, educational policies cannot be divorced from industrial policy, because they are all part of an indivisible system (Narula 2003a). If absorptive capacities and industrial competitiveness are to be fostered, it behoves policy makers to appreciate the systemic nature of knowledge creation and diffusion, as well as the crucial importance of promoting the efficiency of institutions that underlay them 


\section{Bibliography}

Abramovitz, M. (1986). “Catching up, forging ahead, and falling behind”, in Journal of Economic History, June, Vol. 46(2), pp. 385-406.

—. (1995). “The elements of social capability”, in D.H. Perkins, and B.H. Koo (eds.), Social capability and long-term growth, Basingstoke, Macmillan Press.

Arundel, A.; Geuna, A. (2001). "Does proximity matter for knowledge transfer from public institutes and universities to firms”? SPRU Electronic Working Paper Series No. 73.

Borensztein, E.; De Gregorio J.; Lee, J.W. (1998). "How does FDI affect economic growth”, in Journal of International Economics, Vol. 45, pp. 115-135.

Cantwell, J. (1991). "The theory of technological competence and its application to international production”, in D. McFetridge,(ed.), Foreign investment, technology and economic growth, Calgary, University of Calgary Press.

Cohen, W.M.; Levinthal, D. (1989). "Innovation and learning: The two faces of R\&D”, in The Economic Journal, Vol. 99, pp. 569-96.

—. (1990). “Absorptive capacity: a new perspective on learning and innovation”, in Administrative Science Quarterly, Vol. 35, pp.128-52.

Criscuolo, P.; Narula, R. (2002). “A novel approach to national technological accumulation and absorptive capacity: Aggregating Cohen and Levinthal”, MERIT Research Memorandum 2002-16.

Dahlman, C.; Nelson, R. (1995). "Social absorption capability, national innovation systems and economic development”, in D.H. Perkins, and B.H. Koo (eds.), Social capability and long-term growth, Basingstoke, Macmillan Press.

Edquist, C. (1997). Systems of innovation, London, Pinter.

—. Hommen, L.; McKelvey, M. (2001) Innovations and employment: Process versus product innovation, Cheltenham, Edward Elgar.

Etzkowitz, H.; Leydesdorff, L. (2000). ”The dynamics of innovation: From national systems and "Mode 2" to a triple helix of university-industry-government relations", Research Policy, Vol. 29, No. 2, pp. 109-23. 
Fagerberg, J. (1994). "Technology and international differences in growth rates', in Journal of Economic Literature, Vol. 32, pp. 1147-75.

Findlay, R. (1978).0 'Relative backwardness, direct foreign investment, and the transfer of technology: a simple dynamic model', Quarterly Journal of Economics, Vol. 92, pp. 1-16.

Fransman, M. (1984). "Technological capability in the Third World: An overview and introduction to some of the issues raised in this book”, in M. Fransman and K. King (eds.), Technological capability in the third world, London, Macmillan Press.

Freeman, C. (1992). "Formal scientific and technical institutions in the national system of innovation”, in B. Lundvall, (ed.), National Systems of Innovation: Towards a theory of innovation and interactive learning, London, Pinter Publishers.

—. Soete, L. (1997). The economics of industrial innovation, Third edition, Pinter.

Glass, A.J.; Saggi, K. (1998). “International technology transfer and the technology gap”, in Journal of Development Economics, Vol. 55, pp. 369-98.

Hagedoorn, J.; Narula, R. (2001). ”Evolutionary understanding of corporate foreign investment behaviour: US foreign direct investment in Europe”, in R. Narula, (ed.), International trade, Investment in a globalizing world, New York, Pergamon.

James, J.; Romijn, H. (1997). "The determinants of technological capability: A crosscountry analysis”, in Oxford Development Studies, Vol. 25, pp. 189-207.

JIBICI (2002). “Foreign direct investment and development: Where do we stand?”, Japan Bank for International Cooperation, Research Paper No. 15.

Johnson, B. (1992). “Institutional Learning”, in B. Lundvall, (ed.), National systems of innovation: Towards a theory of innovation and interactive learning, London, Pinter.

Kapstein, E. (2002) "Virtuous circles? Human capital formation, economic development and the multinational enterprise”, OECD Technical Papers No. 191.

Karaomerlioglu, D.; Ansal, H. (2000). Innovation and employment in developing countries, in M. Vivarelli and M. Pianta (eds.), The employment impact of innovation, Routledge, London.

Katrak, H. (2002). “Does economic liberalisation endanger indigenous technological developments? An analysis of the Indian experience”, in Research Policy Vol. 31, pp. 19-30. 
Kim, L. (1995). “Absorptive capacity and industrial growth: A conceptual framework and Korea's experience”, in D.H. Perkins and B.H. Koo (eds.), Social capability and long-term growth, Basingstoke, Macmillan Press.

Lall, S. (1992). “Technological capabilities and industrialization”, in World Development, Vol. 2, No. 2, pp.165-86.

—. (1996). Learning from the Asian Tigers, Basingstoke, Macmillan.

—. (1997a) "East Asia”, in J.H. Dunning (ed.), Governments, globalisation and international business, Oxford, Oxford University Press, pp. 407-30.

—. (1997b). "Policies for industrial competitiveness in developing countries: Learning from Asia”, Report prepared for the Commonwealth Secretariat, Oxford.

—. (2003a). "Foreign direct investment, technology development and competitiveness: Issues and evidence”, in S. Lall and S. Urata (eds.), Competitiveness, FDI and technological activity in East Asia, Cheltenham, Edward Elgar, pp. 12-56.

—. (2003b). "The role of government policy in building industrial competitiveness in a globalizing world”, Paper written for The Intergovernmental Group on Monetary Affairs and Development, (G-24), first draft, August.

Lee, K-R. (2001). “Technological catching-up through overseas direct investment Samsung's camera business”, in F. Sachwald (ed.), Going multinational. The Korean experience of foreign direct investment, London, Routledge, pp. 275-314.

Lundvall, B. (ed.), (1992). National systems of innovation: Towards a theory of innovation and interactive learning, London, Pinter Publishers.

McGaughey, S. (2002). "Strategic interventions in intellectual asset flows”, Academy of Management Review, Vol. 27, No. (2), pp. 248-74.

Myrdal, G. (1957). Economic theory and under-developed regions, London, Duckworth.

Narula, R. (1996). Multinational investment and economic structure, London, Routledge.

- . (2002). Switching from import substitution to the 'New Economic Model' in Latin America: A case of not learning from Asia, MERIT research Memorandum 2002-32.

- (2003a). Globalisation and technology: Interdependence, innovation systems and industrial policy, Cambridge, Polity Press.

-. (2003b). "Multinational firms, regional integration and globalizing markets: Implications for developing countries”, in R. Devlin and A. Estevadeordal, (eds.), 
Trade and regional integration in the development agenda, Washington DC., InterAmerican Development Bank.

—. Dunning, J. (2000). "Industrial development, globalisation and multinational enterprises: New realities for developing countries”, in Oxford Development Studies, Vol. 28, No.2, pp. 141-67.

—. Marin, A. (2003). "FDI spillovers, absorptive capacities and human capital development: Evidence from Argentina”, MERIT Research Memorandum 2003-16.

—. Wakelin, K. (1998). "Technological competitiveness, trade and foreign direct investment”, in Structural change and economic dynamics, Vol. 9, pp. 373-87.

Oyelaran-Oyeyinka, B.; Barclay, L. (2003). "Systems of innovation and human capital in African development”, UNU-INTECH Discussion Paper Series 2003-2.

Perez, C.; Soete, L. (1988). “Catching-up in technology: Entry barriers and windows of opportunities”, in Dosi et al., Technical change and economic theory, New York, Columbia University Press.

Pianta, M. (2000). “The employment impact of product and process innovations”, in M. Vivarelli and M. Pianta (eds.), The employment impact of innovation, London, Routledge.

—. (2004). "Innovation and employment”, in J. Fagerberg, D. Mowery and R. Nelson (eds.), Handbook of Innovation, Oxford, Oxford University Press.

Ramos, J. (2000). "Policy directions for the new economic model in Latin America”, in World Development, Vol. 28, pp. 1703-17.

Rasiah, R. (2002). "Infrastructure and domestic patents in developing Asia”, mimeo, UNU/INTECH, Maastricht.

Ritchie, B. (2002). "Foreign direct investment and intellectual capital formation in South East Asia”, OECD Technical Papers No. 194.

Rodrik, D.; Subramanian A.; Trebbi, A. (2002). "Institutions rule: The primacy of institutions over geography and integration in economic development, NBER Working Paper 9305.

Sachwald, F. (2001). “Globalisation and Korea’s development trajectory”, in F. Sachwald (ed.), Going multinational. The Korean experience of foreign direct investment, London, Routledge, pp. 361-82. 
Slaughter, M. (2002). "Skill upgrading in developing countries: Has inward foreign direct investment played a role?” OECD Technical Papers No. 192.

Smith, K. (1997). "Economic infrastructures and innovation systems”, in C. Edquist (ed.), Systems of innovation: technologies, institutions and organizations, London and Washington, Pinter.

Spiezia, V.; Vivarelli, M. (2002). “Innovation and employment: A critical survey”, in N. Greenan, Y. L’Horty and J. Mairesse (eds.) Productivity, inequality and the digital economy, Cambridge, MA., MIT Press.

Suh, Joonghae (2000). "Korean innovation system: Challenges and new policy agenda”, mimeo, Maastricht.

Viotti, E. (2002). “National learning systems: A new approach on technological change in late industrializing economies and evidences from the cases of Brazil and South Korea”, in Technological Forecasting and Social Change, Vol. 69, pp. 653-80.

$\mathrm{Xu}$, B. (2000). "Multinational enterprises, technology diffusion, and host country productivity growth”, in, Journal of Development Economics, Vol. 62, pp. 477-93.

Zahra, S.; George, G. (2002) Absorptive capacity: a review, reconceptualization and extension, Academy of Management Review, Vol 27, pp 185-203. 